\title{
Macroalgal Bioindicators of Recovery from Eutrophication in a Tidal Lagoon Following Wastewater Diversion and Earthquake Disturbance
}

\author{
Neill Barr ${ }^{1} \cdot$ John $_{\text {Zeldis }}{ }^{2} \cdot$ Kristin Scheuer $^{3} \cdot$ David Schiel $^{3}$ \\ Received: 22 October 2018 / Revised: 25 September 2019 / Accepted: 7 October 2019 / Published online: 20 December 2019 \\ (C) The Author(s) 2019
}

\begin{abstract}
Together, macroalgal tissue biochemical nitrogen indices ( $\mathrm{N}$-indices) and macroalgal abundance can be used as bioindicators of $\mathrm{N}$-enrichment in estuaries. In this study, we examine the extent and rates of response of Ulva bioindicators during rapid Nenrichment perturbations in the eutrophic Avon-Heathcote Estuary (AHE) (Christchurch, New Zealand). With the diversion of the city's wastewater discharge away from the estuary in March 2010, a 90\% reduction in the estuary's N-concentration was expected. In turn, this was expected to reduce macroalgal biomass and improve the overall trophic condition of the estuary. We surveyed Ulva bioindicators over a five-year period spanning the diversion. There was a rapid (within one year) transition away from eutrophic condition reflected in N-indices (tissue-chlorophyll, -free amino acids, $-\mathrm{N}$ and $-\delta^{15} \mathrm{~N}$ ) following wastewater diversion, towards values corresponding with 'cleaner' water quality. This was accompanied by large reductions in Ulva percent cover, based on seasonal surveys conducted from 2001 to 2014. However, two large earthquakes in February and June 2011 caused a breakdown of the city's wastewater infrastructure, resulting in overflows of untreated sewage into the estuary between February and November 2011. The re-enrichment of $\mathrm{N}$ and changes in N-sources (treated versus untreated sewage) were rapidly reflected in Ulva bioindicators, notably $\delta^{15} \mathrm{~N}$. Following repair of infrastructure, Ulva bioindicators again reverted towards a less eutrophic state. Overall, bioindicators were sensitive to changes in $\mathrm{N}$-availability and $\mathrm{N}$-source, and useful for identifying the position of algal populations on a eutrophic-to-oligotrophic gradient. These attributes demonstrated their utility as adjuncts to water quality monitoring and algal biomass surveys.
\end{abstract}

Keywords Estuary eutrophication - Ulva $\cdot$ Bioindicators · Wastewater nitrogen · Avon-Heathcote Estuary $\cdot$ Earthquake disturbance

\section{Introduction}

Urbanisation, deforestation, agricultural intensification and fertiliser application (Fowler et al. 2013) have resulted in

Communicated by Lijun Hou

Neill Barr

neill.barr@niwa.co.nz

1 National Institute for Water and Atmospheric Research, 301 Evans Bay Parade, Wellington, New Zealand

2 National Institute for Water and Atmospheric Research, 10 Kyle Street, Riccarton, Christchurch, New Zealand

3 University of Canterbury, Private Bag 4800, Christchurch, New Zealand increased nutrient loading to estuaries and other aquatic ecosystems globally (Nixon 1995; GESAMP 2001; Jones et al. 2018). Increased nutrient loading has, in turn, caused increases in primary production of macroalgae leading to nuisance blooms, often notably of the genera Ulva and Gracilaria, with both direct and indirect effects on sediment chemistry, biotic interactions and biodiversity in estuaries (Morris 1991; Sfriso et al. 1991; Bokn et al. 2002; Savage et al. 2002; Sutula et al. 2014). Consequently, monitoring and control of nuisance macroalgal blooms have become a primary objective in management of coastal systems impacted by nutrient pollution (Sfriso et al. 1991; NRC 2000; Sutula et al. 2014).

In temperate estuaries, nitrogen $(\mathrm{N})$ is generally the primary limiting nutrient during peak seasonal growth for macroalgae (Hanisak 1983), such as Ulva and Gracilaria (Rosenberg and Ramus 1982). For this reason, water column $\mathrm{N}$ is commonly monitored in coastal systems, often in support of management frameworks designed for the purpose of eutrophication control 
(ANZECC 2000; NRC 2000; EU Water Framework Directive 2000/60/EC). Such monitoring typically consists of conventional measures of water quality through water column nutrient sampling. However, physical, chemical and biological processes of estuarine systems are constantly changing as they are influenced by freshwater runoff, other terrestrial inputs, and tidal exchange of water with the adjacent open sea (Flindt et al. 1999). Consequently, sampled nutrient concentrations in shallow estuaries can vary significantly in space and time, making monitoring of concentrations problematic for assessing trophic condition (as a function of $\mathrm{N}$ loading). This can be further exacerbated by the capacity of fast-growing macroalgae to rapidly take up $\mathrm{N}$ and other nutrients, particularly when in high biomass, decoupling observed concentrations from algal productivity and biomass (Björnsäter and Wheeler 1990; Thybo-Christesen et al. 1993; Valiela et al. 1997; Fong et al. 1998; Flindt et al. 1999). Together, these factors underlie the often observed lack of correlation in estuaries between water column $\mathrm{N}$ (and nutrient) concentrations, and either productivity or growth of the primary producers that ultimately drive trophic condition (Fong and Zedler 1993; Fong et al. 1998).

To improve understanding of macroalgal productivity in response to $\mathrm{N}$-availability, and to develop macroalgal bioindicators, early research focused on the N-status of macroalgae as an index of seawater $\mathrm{N}$-availability (Atkinson and Smith 1983; Björnsäter and Wheeler 1990; Peckol et al. 1994; Fong et al. 1998). Historically, total tissue-N content or the ratio of nitrogen/carbon (N:C) was typically used as measures of N-status in studies of microalgae (Flynn et al. 1989) and macroalgae (Atkinson and Smith 1983; Björnsäter and Wheeler 1990; Peckol et al. 1994; Fong et al. 1998). However, other research has examined the responses of other tissue $\mathrm{N}$-indices in macroalgae, including tissue-chlorophyll (Buapeta et al. 2008) and free amino acids (FAA) (Jones et al. 1996; Costanzo et al. 2001; Barr and Rees 2003; Costanzo et al. 2005; Barr et al. 2013) to $\mathrm{N}$-availability, with positive results. There is also the longknown relationship between tissue- $\mathrm{N}$ content, in the various internal N-storage pools of some macroalgae, and potential growth rate when other requirements, particularly light and temperature (Duke et al. 1989), are not limiting for growth (Björnsäter and Wheeler 1990; McGlathery et al. 1996). Therefore, monitoring tissue N-status in Ulva (and potentially other bloom-forming algae) in relation to changes in $\mathrm{N}$-availability in the environment can improve understanding and aid management of such proliferations (e.g. Fong et al. 1998).

Stable isotopes of $\mathrm{N}$ and $\mathrm{C}\left(\delta^{15} \mathrm{~N}\right.$ and $\left.\delta^{13} \mathrm{C}\right)$ in sediment, water and biota, including those developed as bioindicators in marine ecosystems (e.g. McClelland et al. 1997; Rogers 1999; Cloern et al. 2002; Rogers 2003; Cohen and Fong 2005, 2006; Lemesle et al. 2016; Jones et al. 2018), also offer unique information about the dominant available sources of $\mathrm{N}$ that are fixed within these ecosystems. In particular, $\delta^{15} \mathrm{~N}$ tends to vary in coastal systems depending on the predominant $\mathrm{N}$-sources available (and subsequently taken up by primary producers such as macroalgae). Such sources often have characteristic ranges of $\delta^{15} \mathrm{~N}$ values, and include $\mathrm{N}$ from urban (human and industrial) waste, agricultural (fertiliser and animal) waste, and $\mathrm{N}$ derived from natural remineralisation and upwelling processes (Wada et al. 1975; Sigman et al. 2000; Bedard-Haughn et al. 2003). In exposed, open coastal environments, marine sources generally provide the majority of biologically available fixed N (Sharp 1983). In semi-enclosed systems (including tidal lagoons and estuaries) however, $\delta^{15} \mathrm{~N}$ values of the dissolved $\mathrm{N}$ pool may be significantly influenced by terrestrially derived $\mathrm{N}$ (supplied from groundwater and surface water flows). Detection of anthropogenic $\mathrm{N}$ loading in coastal waters requires natural state 'unimpacted' $\delta^{15} \mathrm{~N}$ values for terrestrial and marine-derived water column DIN (dissolved inorganic nitrogen). At large regional or national scales, this requires an understanding of how $\delta^{15} \mathrm{~N}$ baseline values vary spatially and temporally in impacted and unimpacted systems. Barr et al. (2013) created such a baseline for marine-derived $\delta^{15} \mathrm{~N}$ values, recorded in Ulva bioindicator samples, collected from 27 natural populations around New Zealand.

The Avon-Heathcote Estuary (AHE) (Christchurch, New Zealand) has historically suffered from blooms of Ulva and Gracilaria which has largely been attributed to excessive N loading from Christchurch City's main wastewater effluent outfall located in the estuary. The outfall was diverted from the estuary to an ocean outfall in March 2010 and it was predicted that this would result in a $\sim 90 \%$ reduction of $\mathrm{N}$ loading to the estuary. We hypothesised that as a result of the reduction in $\mathrm{N}$, there would also be significant reductions in algal productivity and biomass within 2 years of diversion, and this would also be reflected by biochemical and isotopic indices. We tested the responses of Ulva, as the dominant nuisance macroalgae in the AHE, to the abatement of wastewater-derived nutrient pollution using time-series investigations (of the key environmental and biological parameters) spanning several years before and after the diversion. However, 11 months after the commissioning of the ocean outfall, in February 2011 and again in June 2011, two powerful earthquakes struck Christchurch City. This damaged the city's wastewater infrastructure so that between February and June 2011, an average of 21\% (derived from Christchurch City Council Wastewater Treatment Plant [CWTP] effluent discharge data) of Christchurch's wastewater flow did not reach the ocean outfall, but flowed directly to the AHE as untreated sewage, mainly via the Avon and Heathcote Rivers. Normal wastewater flows to the ocean outfall were fully restored by November 2011. The increase and subsequent decrease of nutrient loading associated with the earthquake provided a further opportunity to study macroalgal responses to eutrophication, along with the March 2010 wastewater diversion to the ocean outfall.

Here, we contribute to the current knowledge by applying these bioindicators in a study that examines large changes in $\mathrm{N}$ 
loading in an estuary undergoing trophic remediation. We compare time-series data of Ulva biochemical $\mathrm{N}$-indices and estimates of Ulva surface percent cover measurements, with conventional water quality data collected over the period of this study. We also place the changes seen in $\mathrm{N}$-indices from the AHE within the context of a New Zealand-wide survey of natural Ulva populations conducted in 2002. Specifically, the study objectives were to test the validity and utility of Ulva bioindicators (biochemical and isotopic $\mathrm{N}$-indices, and percent cover estimates) as 'measures' of change in intensity and source of $\mathrm{N}$ loading to estuaries, and, in this case, examine some of the biotic and abiotic processes involved in remediation of an estuary that has suffered long-term eutrophication.

\section{Methods}

\section{Study Setting}

The AHE is located near Christchurch on the east coast of the New Zealand's South Island. It is a small $\left(7 \mathrm{~km}^{2}\right)$ urban mesotidal lagoon (1.9 m mean depth (HWS), 1.8 mean tidal range) with extensive intertidal area (64\%). It has received the wastewater from Christchurch (with a current population 330,000) for many decades from the Christchurch City Wastewater Treatment Plant (CWTP).
Prior to the diversion of the wastewater discharge to an ocean outfall in March 2010, > $90 \%$ of the estuary's DIN and DRP (dissolved reactive phosphorus) came from this wastewater, with the remaining nutrient loads sourced from its two rivers, the Avon and Heathcote Rivers (Bolton-Ritchie and Main 2005). Median concentrations of total nitrogen (TN) in the inner estuary were between 160 and $330 \mu \mathrm{mol} \mathrm{L}^{-1}$ (Bolton-Ritchie and Main 2005), indicating that AHE was a hypertrophic system (Smith et al. 1999). DIN concentrations (ca. 70 to $110 \mu \mathrm{mol} \mathrm{L}^{-1}$ ) were commonly recorded in the estuary prior to the wastewater diversion (Bolton-Ritchie and Main 2005).

In recent decades, nuisance blooms of Ulva and Gracilaria were growing over its intertidal flats, often at very high biomasses (Knox and Kilner 1973; Steffensen 1974; Bressington 2003; Alexander et al. 2008). Williams (1960) (as cited in Alexander et al. 2008) recorded biomass levels $>4.5 \mathrm{~kg}$ wet weight $/ \mathrm{m}^{2}$ for the western and eastern sides of the AHE and Alexander et al. (2008) recorded biomasses in the western AHE as high as $3.65 \mathrm{~kg}$ wet weight $/ \mathrm{m}^{2}$ (or $1.10 \mathrm{~kg}$ dry weight $/ \mathrm{m}^{2}$ ) which were similar to maximum values reported by Thornber et al. (2017). These levels of macroalgal biomass exceeded those identified by Sutula et al. (2014) as having adverse effects on health of several Californian estuaries. The largest proliferations of Ulva have historically occupied its western and eastern sides, so the study focussed primarily on the western Humphreys Drive area ('Western') and eastern inner side of the Brighton spit ('Eastern') (Fig. 1). These main
Fig. 1 Site locations in the AvonHeathcote Estuary (Christchurch, New Zealand). Locations of water quality sites shown as yellow circles with letters (the ECan site code is in brackets after the site name). A Discharge (SQ30544). B Avon (SQ30541). C Heathcote (SQ30548). D Western (SQ32819). E Eastern (SQ32575). F Mouth (SQ34656). G Shag Rock (SQ30546). Locations of algal percent cover sites shown as white circles with numbers. These sites include the two algal biochemistry monitoring Western (7) and Eastern (1) sites (white circles with indicated red outlines). See also Table 1

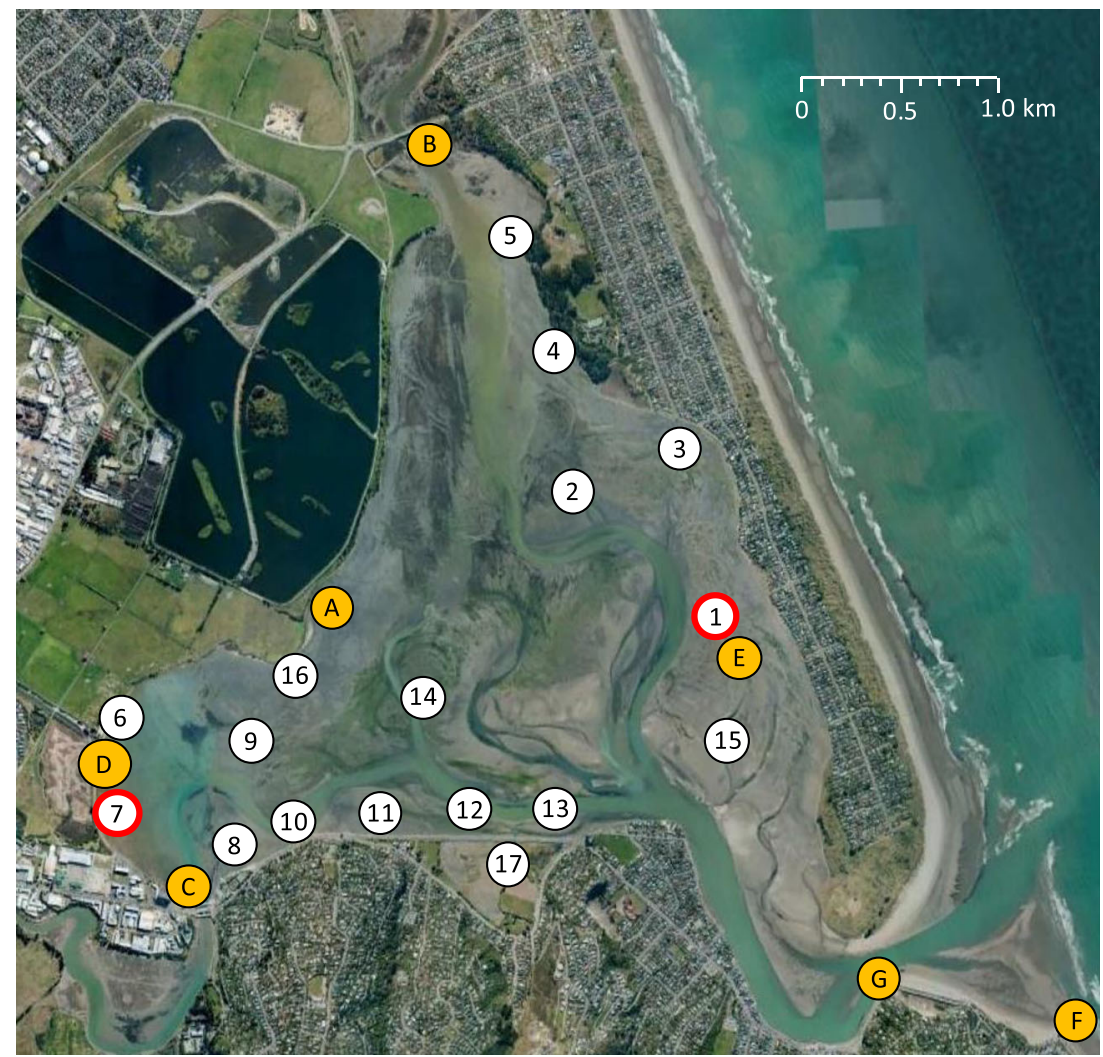


macroalgal beds were sampled monthly from 2009 to 2013, as described below.

\section{Nutrient Water Quality}

Water quality sampling from the AHE (Fig. 1) (Bolton-Ritchie and Main 2005; Bolton-Ritchie 2015) included analyses for the ammonium $\left(\mathrm{NH}_{4}{ }^{+}\right)$, nitrate + nitrite $\left(\mathrm{NO}_{3}{ }^{-}+\mathrm{NO}_{2}{ }^{-}\right.$, hereafter called $\mathrm{NO}_{3}{ }^{-}$), dissolved inorganic nitrogen (DIN, being the sum of ammonium + nitrate + nitrite), total nitrogen (TN), dissolved reactive phosphorus (DRP) and total phosphorus (TP). Water quality data collected by the local regional council, Environment Canterbury (ECan), were extracted for locations nearest our sampling sites. Methods of sample collection and analysis used in the study were described by BoltonRitchie (2015) but nutrient concentrations in collected samples were determined using APHA (1998) Standard Methods for the Examination of Water and Wastewater (i.e. APHA $4500-\mathrm{NO}_{3} \mathrm{~F}$ for $\mathrm{NO}_{3}{ }^{-}+\mathrm{NO}_{2}{ }^{-}, 4500-\mathrm{NH}_{3} \mathrm{~F}$ for $\mathrm{NH}_{3} / \mathrm{NH}_{4}{ }^{+}$, APHA 4500-N C for TN and APHA 4500-P B for DRP). Sampling was monthly and collections were made within $2 \mathrm{~h}$ of high tide at all sites except one, Shag Rock (SQ30546), where sampling was conducted at both high and low tide. This was because the Shag Rock site was located in the main channel where high and low tide samples in theory would reflect the extremes of incoming (i.e. more marine) versus outgoing (i.e. more land-derived) water column nutrient concentrations. For most analysis, the nutrient data used were for $\mathrm{NH}_{4}-\mathrm{N}, \mathrm{NO}_{3}-\mathrm{N}, \mathrm{TN}$ and DRP.

\section{Macroalgal Sampling, Assaying and Analysis}

Sampling of Ulva was conducted sporadically in the estuary from both the western and eastern sites from February 2009, followed by regular monthly collections beginning in November 2009 (Fig. 1). Algal collections were made at low tide from three randomly chosen areas (i.e. giving three separate replicate thalli samples per site at each collection) at the western and eastern sites in the AHE. Sampled macroalgae were attached (i.e. not drifting so reflected in situ conditions), covered with some $(\sim 100 \mathrm{~mm})$ seawater, and the three replicate thalli were selected to standardise for size and overall healthy appearance. For frondose Ulva species (predominately Ulva pertusa), individual larger thalli approximately $200-300 \mathrm{~mm}$ in length were selected. This gave sufficient material $(\sim 3 \mathrm{~g})$ for all the tissue biochemical measurements required. Samples were rinsed in local seawater to wash off sediment and transported to the laboratory in a darkened cooler bin on ice for final processing, frozen storage $\left(-80^{\circ} \mathrm{C}\right)$ and subsequent analysis. For free amino acid (FAA) determination, Ulva tissue acid extraction was done using freshly collected material (prior to freezing $\left(-80{ }^{\circ} \mathrm{C}\right)$ for other analyses: Barr and Rees 2003). FAAs were extracted from Ulva (1 g fresh weight) in $5 \mathrm{ml}$ ice-cold $1 \mathrm{M}$ perchloric acid for $10 \mathrm{~min}$, before neutralising with $1 \mathrm{M} \mathrm{KOH}$ (potassium hydroxide) $/ 0.2 \mathrm{M}$ MOPS (3-(N-morpholino)propanesulfonic acid). FAA content for the above samples was assayed using reverse phase HPLC (High Performance Liquid Chromatography). Concentrations were quantified by comparing with external standards for all individual FAAs and expressed in $\mu \mathrm{mol}-\mathrm{N} \mathrm{g} \mathrm{DW}{ }^{-1}$.

Chlorophyll $a$ and $b$ concentrations were estimated for frozen Ulva tissue samples as described by Barr and Rees (2003). Chlorophyll was extracted in methanol/dimethylsulphoxide $\left(4: 1 \mathrm{v} / \mathrm{v}\right.$ ) (Duncan and Harrison 1982) for $24 \mathrm{~h}$ at $4{ }^{\circ} \mathrm{C}$. Spectrophotometrically derived absorbances were converted to concentrations of chlorophyll $a$ and $b$ using standard formulae (Holden 1965). Concentrations of chlorophyll $a$ and $b$ were expressed as $\mathrm{mg} \mathrm{g} \mathrm{DW}^{-1}$ and then added together to give total chlorophyll $(a+b)$, hereafter referred to as total chlorophyll or just chlorophyll.

For Ulva tissue- $\mathrm{N},-\delta^{15} \mathrm{~N},-\mathrm{C}$ and $-\delta^{13} \mathrm{C}$ analysis, samples were thawed, dried at $60^{\circ} \mathrm{C}$ for $48 \mathrm{~h}$ and then ground to a fine powder. For estimation of the above tissue constituents, a Dumas elemental analyser (Europa Scientific ANCA-SL) interfaced to an isotope mass spectrometer (Europa Scientific 20-20 Stable Isotope Analyser) was used. For tissue- $\delta{ }^{15} \mathrm{~N}$ quantification, samples were analysed against a urea standard/reference with a delta value of $-0.45 \%$. Measurement precision was $\pm 1 \%$. For tissue- $\mathrm{C} \delta{ }^{13} \mathrm{C}$ quantification, samples are analysed against a sucrose standard/ reference with a delta value of $-10.80 \%$. Measurement precision was $\pm 0.3 \%$.

Ulva tissue $\mathrm{N}$-indices were compared between pre- and post-diversion periods. Samples used were from the summer months only (November to January) when N limitation, if any, would be expected to occur. Comparisons of Ulva tissue Nindices, tissue- $\mathrm{N}$, -chlorophyll and -FAA, were made between levels in the pre-diversion summer (2009/2010) and levels of the three post-diversion summers (2010/2011, 2011/2012 and 2012/2013) using the Holm-Sidak method for multiple comparisons (SigmaPlot version 12.5). Ulva N-indices from AHE, from pre- and post-diversion periods, were also compared with $\mathrm{N}$-indices from 27 natural Ulva populations (divided into six environmental categories) from around New Zealand in 2001/2002 (derived from Barr et al. 2013). Included were samples collected from AHE in pre-diversion summers (2001/2002 and 2009/2010), and post-diversion summers (2010/2011 and 2011/2012). Square root transformed values from nine Ulva tissue N-indices: the individual FAAs aspartate, glutamate, asparagine, glutamine, proline, the total remaining FAAs, total chlorophyll, tissue- $\mathrm{N}$ and tissue- $-\delta^{15} \mathrm{~N}$, were used to produce a resemblance matrix. The matrix was then used to generate a Euclidian distance multi-dimensional scaling (MDS) plot that examined relative similarity/ dissimilarity of $\mathrm{N}$-indices in Ulva populations using PRIMER (version 6.1.7). 


\section{Ulva Percent Cover Estimates}

Christchurch City Council (CCC) staff carried out annual summer surveys of visual estimates of percentage cover of Ulva, between 2001 and 2015. It is worth noting that the same surveyor performed all the surveys over this 15-year period. Seventeen survey sites (Fig. 1) were typically surveyed on each survey occasion. Surveys were monthly from November (late spring) to February (late summer), inclusive. The visual assessment method involved assessing the total percentage macroalgal cover within a 5 -m radius of the observer, in an area that was representative of the site in general. The 17 sites were of two types:

1. Ulva 'seed' sites where juveniles could remain attached for a period of initial growth, then once detached could supply new drift Ulva to other areas in the estuary. These areas were typically towards the centre of the estuary and included sites 9, 12 and 14 (Fig. 1).

2. 'Accumulation' sites where drifted and attached Ulva continued to grow and sometimes accumulated on the shore. The heaviest accumulations occurred at site 3 on the eastern side of the estuary, and 6, 7 and 17 on the western, to south-western, side of the estuary. Accumulations were largest at site 7 where drifted Ulva tended to entangle in a large Gracilaria bed here. The remaining sites $(1,4,8,10,11,13$ and 15$)$ had only occasional accumulations and typically low percentage cover in all surveys.

The mean percentage cover for each site surveyed between November and February was calculated for the pre- and postwastewater diversion periods separately (2000/2001 to 2009/ 2010 and 2010/2011 to 2014/2015, respectively). Frequency distributions of these percentage cover estimates were tested for differences between pre- and post-diversion distributions (chi-square), where the expected result under the null hypothesis was that pre- and post-diversion distributions were the same (STATISTICA 2013).

\section{Results}

\section{Nutrient Water Quality}

Nutrient water quality (Table 1) improved for most nutrients at most sites after the March 2010 wastewater diversion to the ocean outfall. Generally, there were clear reductions in $\mathrm{NH}_{4}-\mathrm{N}$ and DRP, although there were minor increases in these nutrients following the earthquakes on 22 February and 13 June 2011 (Fig. 2). Reductions in $\mathrm{NO}_{3}-\mathrm{N}$ following the diversion were less pronounced compared with $\mathrm{NH}_{4}-\mathrm{N}$ because the major source of this nutrient was not the wastewater discharge, but the Avon and Heathcote Rivers. Consequently, the post-diversion reductions in DIN were intermediate between those of $\mathrm{NH}_{4}-\mathrm{N}$ and $\mathrm{NO}_{3}-\mathrm{N}$ (Table 1 and Fig. 3), including no improvement at the Heathcote site. The Shag Rock sampling site, which was routinely sampled at both high and low tides, was informative in terms of the range of difference between high and low tide nutrient concentrations, reflecting either more marine sourced lower concentrations, or more riverine sourced higher concentrations, respectively, to the estuary (Fig. 2).

Mean daily (post-2007) values of DIN loading from the Avon River $\left(156 \mathrm{~kg} \mathrm{day}^{-1}\right)$ were higher than from the Heathcote River (102 kg day ${ }^{-1}$ ) (Barr et al. 2012). Loads peaked in winter (ca. July) when river flow rates were greatest, and usually exceeded $200-300 \mathrm{~kg} \mathrm{day}^{-1}$. The main effects on loads arising from wastewater infrastructure damage caused by the February 2011 earthquake were peaks in summer and autumn of $\mathrm{NH}_{4}-\mathrm{N}$ (and DIN) loads (Fig. 3), whereas summerautumn periods in other years had lower loads.
Table 1 Change in median water column nutrient concentrations $(\mu \mathrm{M})$ before (Jan 2007 to Mar 2010; $n=45$ ) and after (Apr 2010 to Jun 2014; $n=60$ ) the wastewater diversion, measured at water quality monitoring locations in AHE (Fig. 2). Data are for samples collected around high tide, except at Shag Rock for which both high and low tide sampling is shown. Shown are concentrations pre-wastewater diversion/postdiversion (also refer to Fig. 3), percentage change, and probabilities (Mann-Whitney) that the pre- and post-diversion concentrations were from the same populations $(*<0.05, * *<0.01, * * *<0.001$, ns: not significant)

\begin{tabular}{|c|c|c|c|c|}
\hline Site/ECAN no. & $\mathrm{NH}_{4}-\mathrm{N}$ & $\mathrm{NO}_{3}-\mathrm{N}$ & DIN & DRP \\
\hline A, Discharge (SQ30544) & $86 / 12,-86 \%$ *** & $17 / 16,-8 \% \mathrm{~ns}$ & $102 / 28,-73 \% * * *$ & $7.0,1.4,-82 \% * * *$ \\
\hline B, Avon (SQ30541) & $43 / 8,-82 \% * * *$ & $33 / 21,-35 \% * *$ & $76 / 30,-62 \% * * *$ & $4.2,1.0,-76 \% * * *$ \\
\hline C, Heathcote (SQ30548) & $20 / 10,-52 \% * * *$ & $66 / 79,20 \% \mathrm{~ns}$ & $86 / 88,3 \% \mathrm{~ns}$ & $3.1,1.3,-57 \% * * *$ \\
\hline D, Western (SQ32819) & $29 / 6.5,-78 \% * * *$ & $22 / 19,-13 \%$ n.s & $51 / 26,-50 \% * * *$ & $3.5,0.9,-74 \% * * *$ \\
\hline E, Eastern (SQ32575) & $20 / 3,-87 \% * * *$ & $8 / 3,-60 \% * *$ & $28 / 6,-79 \% * * *$ & $2.7,0.7,-75 \%$ *** \\
\hline F, Mouth (SQ34656) & $9 / 1,-88 \% * * *$ & $3 / 2,-34 \% * *$ & $12 / 3,-75 \% * * *$ & $1.1,0.5,-59 \% * * *$ \\
\hline G, Shag Rock high tide (SQ30546) & $4.7 / 0.4,-92 \% * * *$ & $1.9 / 1.6,-4 \% \mathrm{~ns}$ & $8 / 2.9,-67 \%$ *** & $0.7,0.2,-72 \% * * *$ \\
\hline G, Shag Rock low tide (SQ30546) & $59 / 4.4,-92 \% * * *$ & $15 / 9,-43 \% * * *$ & $81 / 16,-81 \% * * *$ & $5.8,0.9,-85 \%$ *** \\
\hline
\end{tabular}


Fig. 2 Long-term changes in seawater nutrient concentrations at Shag Rock water quality sampling station (SQ30546) at high tide (unfilled triangles) and low tide (black triangles). The diversion and the February (EQ1) and June 2011 (EQ2) earthquakes are shown by dashed lines

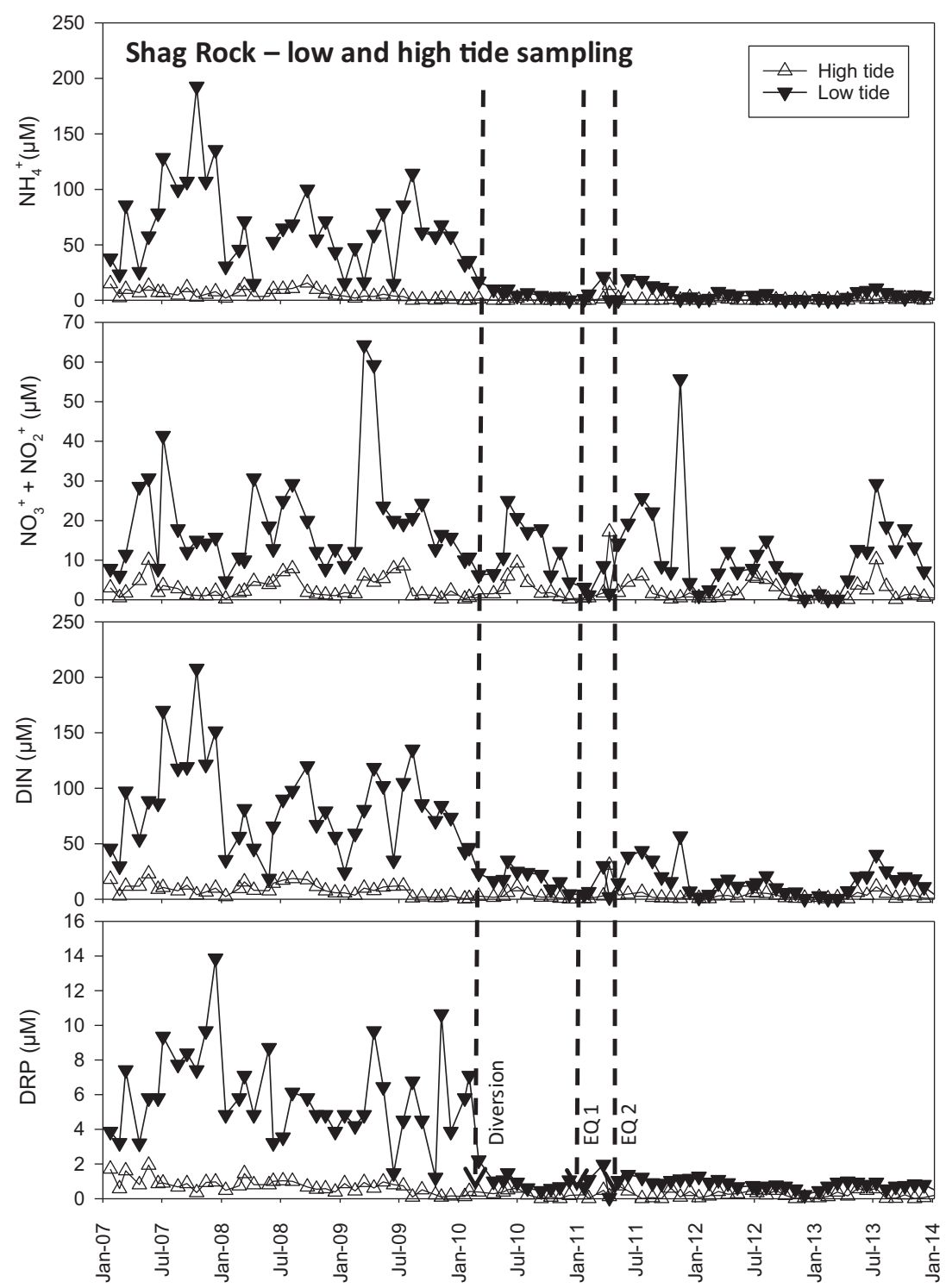

\section{Algal Biochemical Monitoring}

Changes in estuary N-supply from 2007 through to June 2014 were compared with changes in $\mathrm{N}$-indices of seawater $\mathrm{N}$ availability (tissue-chlorophyll, -FAA, $-\mathrm{N}$ and $-\delta^{15} \mathrm{~N}$ content) in frondose Ulva populations from the eastern and western collection sites. Ulva chlorophyll content followed similar 'step-shift' trends as seawater DIN concentration going from higher average pre-diversion levels (from February 2009) through to lower average post-diversion (March 2010 to January 2013) levels. Following the wastewater diversion, there was a significant reduction in seawater DIN concentrations (Table 1, Fig. 4) at both western and eastern sites. This was accompanied by reductions in chlorophyll content in Ulva from both the western and eastern sites, but the response was clearer at the eastern site where the DIN reduction was greater (Figs. 4). Seawater DIN concentrations increased at both sites following the February and June 2011 earthquake series (Fig. 4) which resulted in overflows of raw effluent into the estuary. Ulva chlorophyll content also increased slightly at the eastern site during the earthquake period then decreased from November 2011 when the last of the major overflows to the two rivers were repaired. However, it remained higher at the western site where DIN levels also remained higher.

One year prior to the diversion, tissue- $\mathrm{N}$ and $-\mathrm{N}: \mathrm{C}$ ratios in Ulva (Fig. 5) showed relatively little seasonal variation at both the western and eastern sites (i.e. they remained relatively constant from January 2009 to January 2010). However, post-diversion, there were two obvious summer tissue- $\mathrm{N}$ minima in 2010/2011 and 2012/2013. The summer tissue-N minima in 2011/2012 was less pronounced at both sites, and possibly may have indicated $\mathrm{N}$ from residual overflows caused by the earthquakes. Prior to the diversion in the late summer of 2009 and summer 2010, Ulva tissue-N remained at high 
Fig. 3 Nitrogen-loading rates in the Heathcote and Avon Rivers, calculated using daily mean river flow rates derived from Gloucester Street NIWA Hydrostation [66602] for the Avon River and from Buxton Terrace NIWA Hydro-station [66612] for the Heathcote River. Flows were calculated from 13-day median values centred on days when nutrient samples were collected from ECan river water quality monitoring sites at Ferrymead Bridge (SQ30548) for the Heathcote River and at Bridge Street (Sth Brighton) Bridge (SQ30597) for the Avon River. The diversion and the February (EQ1) and June 2011 (EQ2) earthquakes are shown by dashed lines

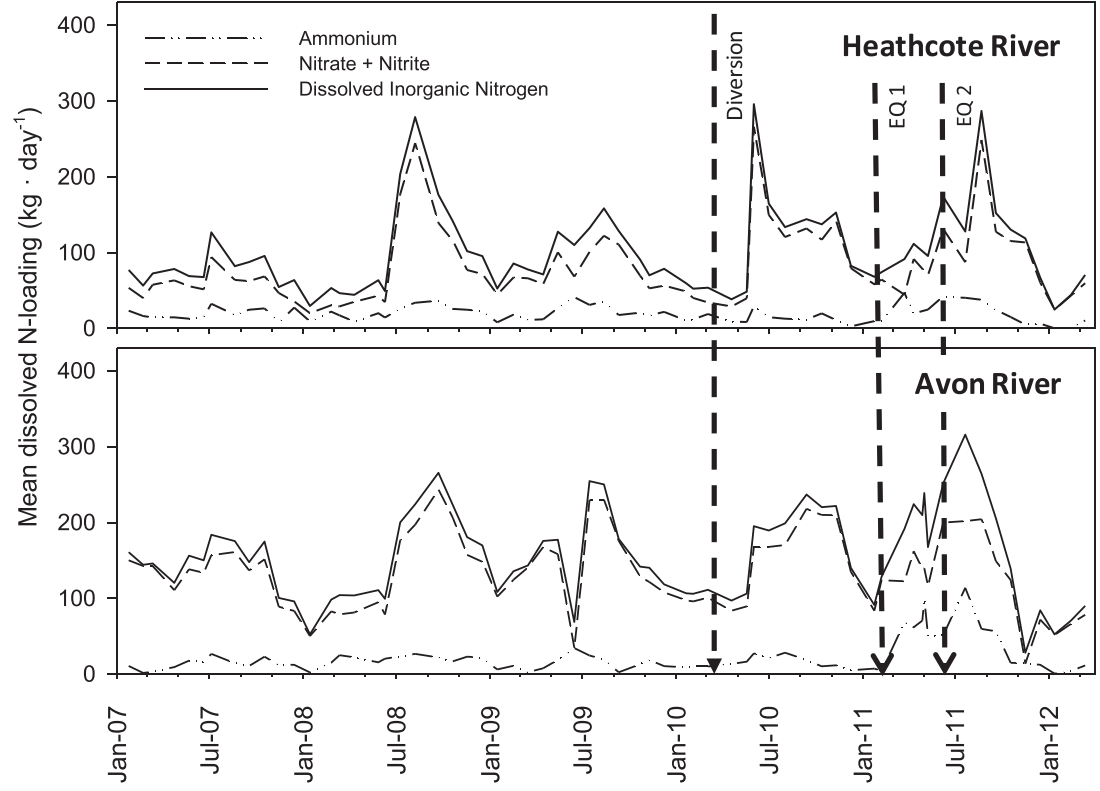

(saturated) levels ( $\sim \%$ ), whereas tissue-N levels declined in the post-diversion summers. This was presumably because tissue-N pools were now being depleted (due to lower postdiversion seawater $\mathrm{N}$-availability) to maintain summer growth (see Discussion).

Comparisons between pre- and post-diversion values of $\mathrm{N}$ indices in Ulva for summer (Fig. 6) showed that for tissue-N, chlorophyll and FAA contents, there was a distinct, and in most cases statistically significant decrease after the diversion, at both western and eastern sites (strongest for chlorophyll and FAA content at the eastern site). Another observation worth noting is that although not specifically (or statistically) compared, N-indices, particularly those of FAA, from the western site were generally slightly lower than those recorded in Ulva from the eastern site. By the end of this study, there were marked declines in tissue- $\mathrm{N}$ to $<2 \%$ at the eastern site and to $\sim 3 \%$ at the western site, compared with pre-diversion levels of around $4 \%$.

Prior to the diversion, $\mathrm{N}$-isotopic $\left(\delta^{15} \mathrm{~N}\right)$ composition of Ulva (Fig. 7) showed an apparent seasonal shift in tissue- $\delta{ }^{15} \mathrm{~N}$ values with winter minima and summer maxima at both the western and eastern sites. Immediately post-
Fig. 4 Changes in seawater DIN concentrations (unfilled circles) at the western (SQ32819) and eastern (SQ32575) sites, and tissuechlorophyll $(a+b)$ content (means $\pm \mathrm{SE}$ ) in Ulva (black filled circles). The dashed trace is the moving DIN average in each plot. The diversion and the February (EQ1) and June 2011 (EQ2) earthquakes are shown by dashed lines

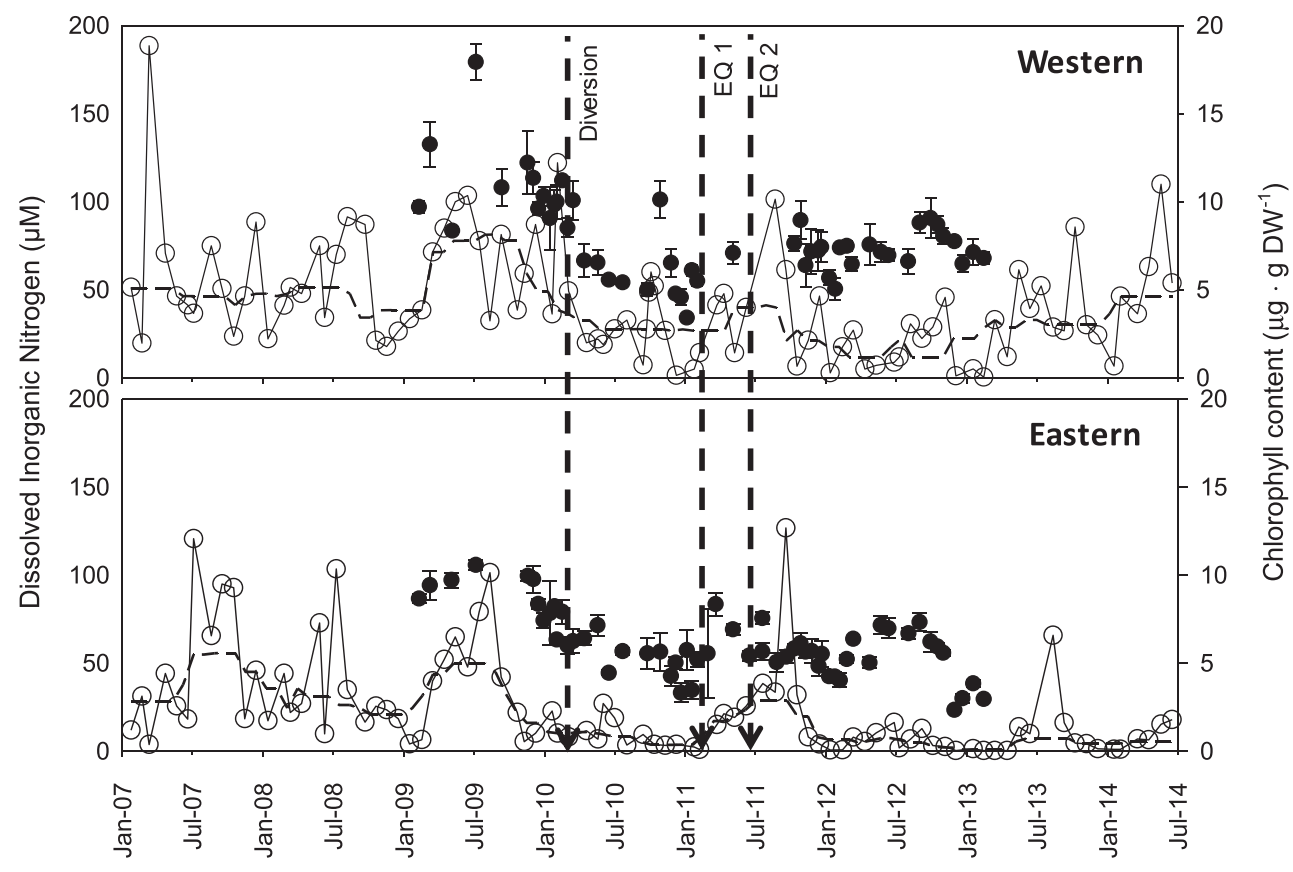


Fig. 5 Changes in tissue-N (means \pm SE: solid line) and N/C (broken line) content in Ulva at the western and eastern sites. The diversion and the February (EQ1) and June 2011 (EQ2) earthquakes are shown by dashed lines. The vertical shaded bars are centred on the summer months

(November to February inclusive)

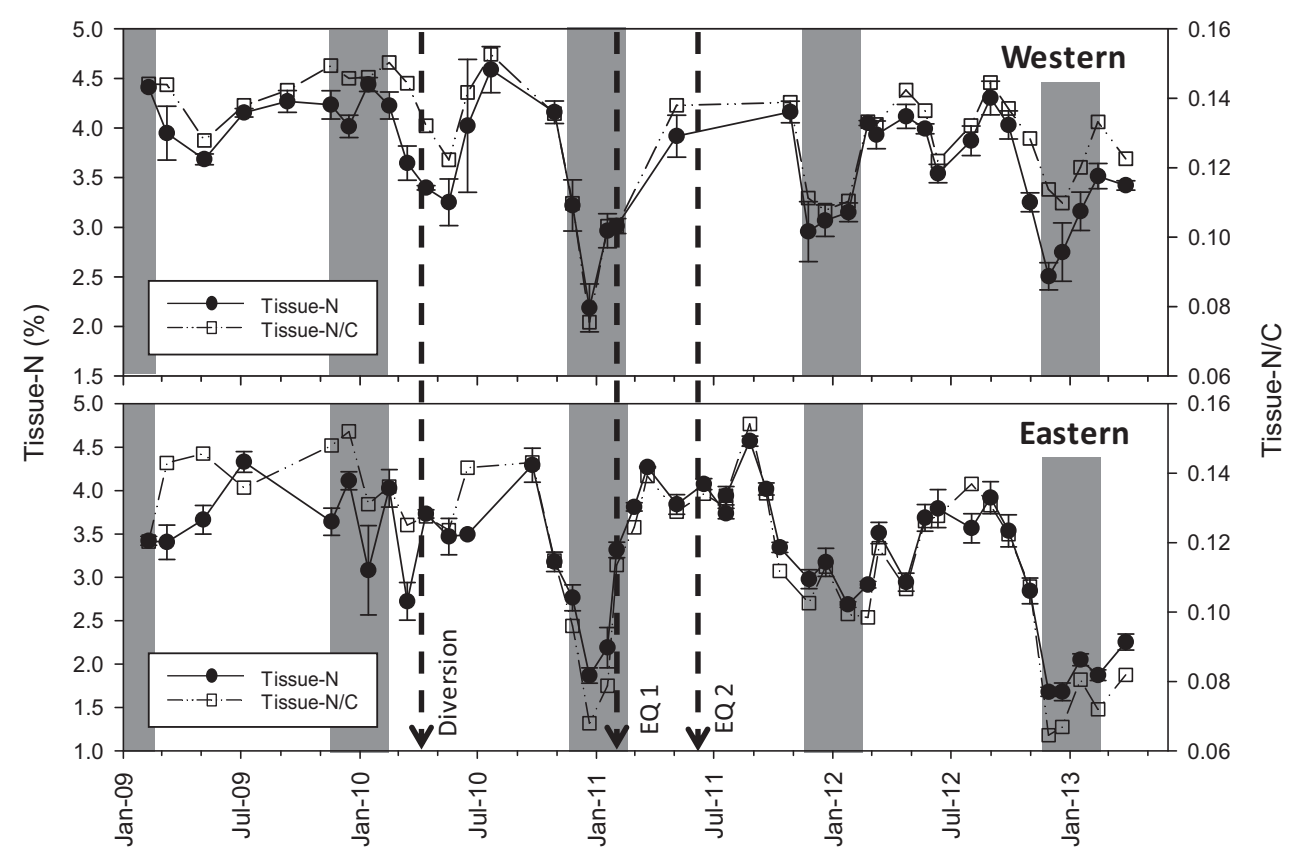

Fig. 6 Comparison of three tissue status $\mathrm{N}$-indices (means $\pm \mathrm{SE}$ ) in Ulva averaged for summer periods at the western and eastern sites for pre-diversion (2009/2010) and post-diversion 2010/2011, 2011/2012 and 2012/ 2013 summers. Values were calculated from four monthly samples (November, December, January and February) each summer. Values and arrows above the bars indicate the magnitude and direction of change in the Nindices in the post-diversion summers relative to pre-diversion summer, with bold values indicating significant differences $(P<$ 0.05: Holm-Sidak method for multiple comparisons; * indicates not significant). Dashed lines in each plot represent mean values of the tissue status $\mathrm{N}$-indices in Ulva from non-polluted sheltered rural sites in summer 2002 (from Barr (2007); see Discussion)

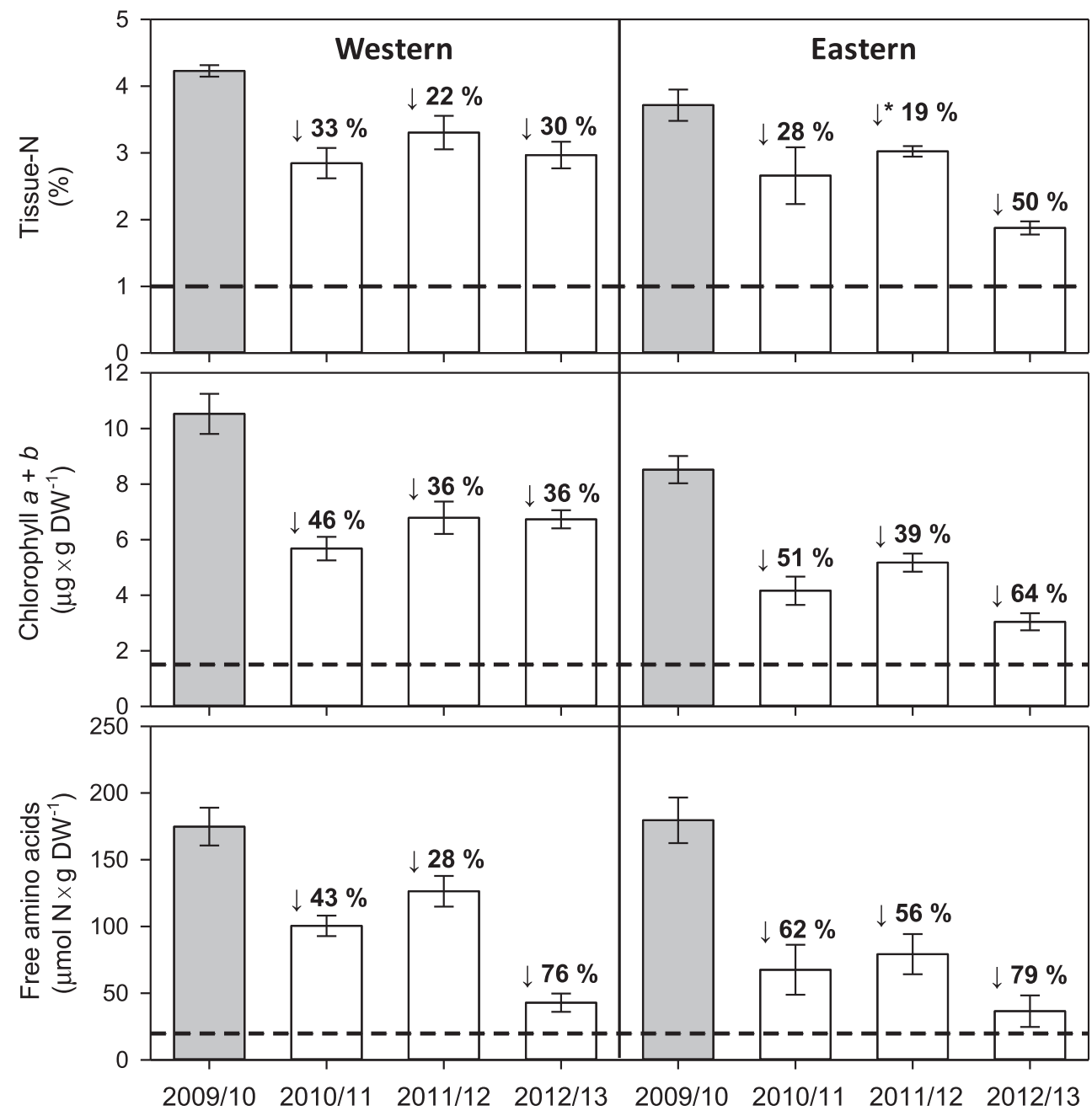


Fig. 7 Changes in Ulva tissue$\delta^{15} \mathrm{~N}$ at the western and eastern sites (means $\pm \mathrm{SE}$ ), determined from three samples collected on each sampling occasion. The shaded region represents the expected coastal marine baseline levels for tissue- $\delta^{15} \mathrm{~N}$ in Ulva in open coastal areas of New Zealand (6.6-8.8\%o; Barr et al. 2013. See Discussion). The diversion and the February (EQ1) and June 2011 (EQ2) earthquakes are shown by dashed lines

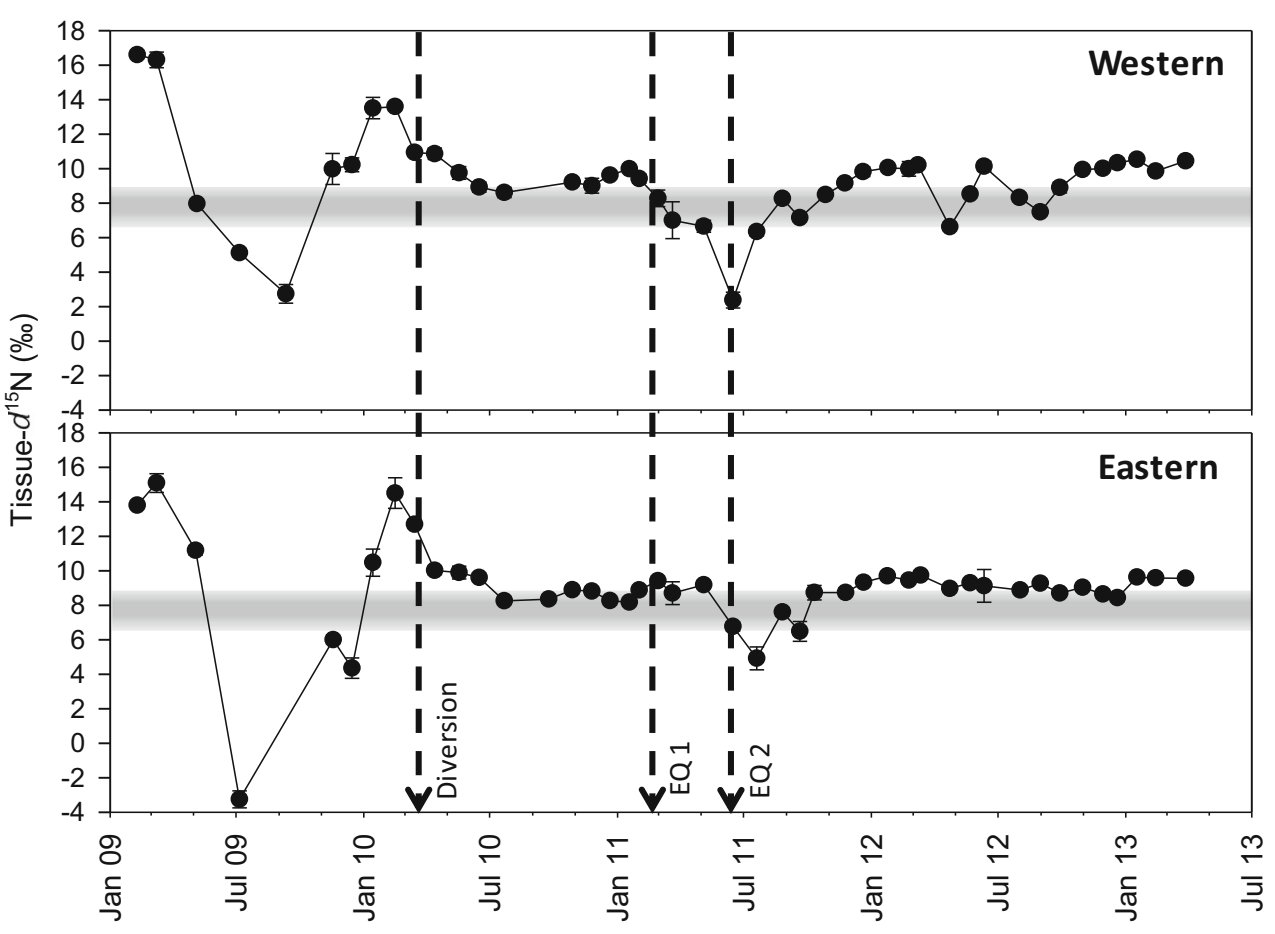

diversion, Ulva tissue- $-{ }^{15} \mathrm{~N}$ values plateaued at around $9 \%$ by July 2010 at both sites, but by July 2011 (during the wastewater overflows arising from the earthquakes), tissue- $\delta{ }^{15} \mathrm{~N}$ values had again dropped to low values on both sides of the estuary. From January 2012 onwards, values again levelled off to around $9 \%$ at the eastern site and $10 \%$ at the western site, but with more variability at the western site.

We compared Ulva tissue N-indices from AHE with samples collected from 27 sites in AHE and elsewhere in New Zealand in 2002 (Barr et al. 2013), using multivariate (MDS) analyses of summer tissue-FAAs, -chlorophyll, $-\mathrm{N}$ and $-\delta^{15} \mathrm{~N}$ (Fig. 8). Across $\mathrm{NZ}$, there was clear separation of urban enriched samples with Ulva from all other environmental categories examined (Fig. 8a). Compared with Ulva from enriched urban estuaries, which included AHE samples in 2002 and 2009, post-diversion Ulva samples collected in summer 2010/2011 and 2011/2012 showed a clear shift of $\mathrm{N}$-indices away from the enriched urban category towards those of lower $\mathrm{N}$ loading indicted by Ulva samples from clean sites (Fig. 8b).

\section{Ulva Percentage Cover}

When the time-series of percentage cover estimates of Ulva were analysed with respect to the timing of the wastewater diversion, there was a clear reduction in median percentage cover across the sites that typically supported the heaviest accumulations (sites 3, 6, 7, 17: > 20\% cover, pre-diversion, Fig. 9a). These included sites 3 in the eastern AHE, and 6, 7 and 17 in the western AHE where large accumulations and high Ulva beach-cast biomass were previously common. The large percentage cover reductions at sites 6 and 7 occurred within the first summer post-diversion (2010-2011: not shown) indicating rapid response to improved water quality conditions. Exceptions to the pattern of post-diversion Ulva cover reductions occurred at sites where Ulva was always rare (sites 1, 2, 4 and 5, Fig. 9a). Sites known to support perennially moderate (up to 50\%) cover of Ulva ('seed sites', see Discussion) also showed little change in median percentage cover. These were sites 9,12 and 14 (Fig. 9a).

The frequency distribution of samples of Ulva percentage cover showed a shift between pre- and post-diversion (Fig. 9b). There were large, significant $(P<0.001)$ reductions in percentage cover frequencies, most notably in the 10 to $<$ $60 \%$ cover categories, post-diversion, compared to pre-diversion. There was a corresponding increase in the 0 to $<10 \%$ cover category from 45 to $75 \%$ of the observations. Between pre- and post-diversion, the mean values of the percentage cover distributions decreased from 20.2 to $12.7 \%$ and the medians decreased from 12.1 to $2.8 \%$ (Fig. 9b).

\section{Discussion}

\section{Ulva as a Bioindicator of $\mathbf{N}$ Loading}

We found significant biochemical and abundance responses of AHE Ulva to variation in nutrient loading arising from both the wastewater diversion and the earthquakes. These macroalgal responses integrated changes in seawater N-availability reflected literally across a whole estuary, at two well-separated eastern and 


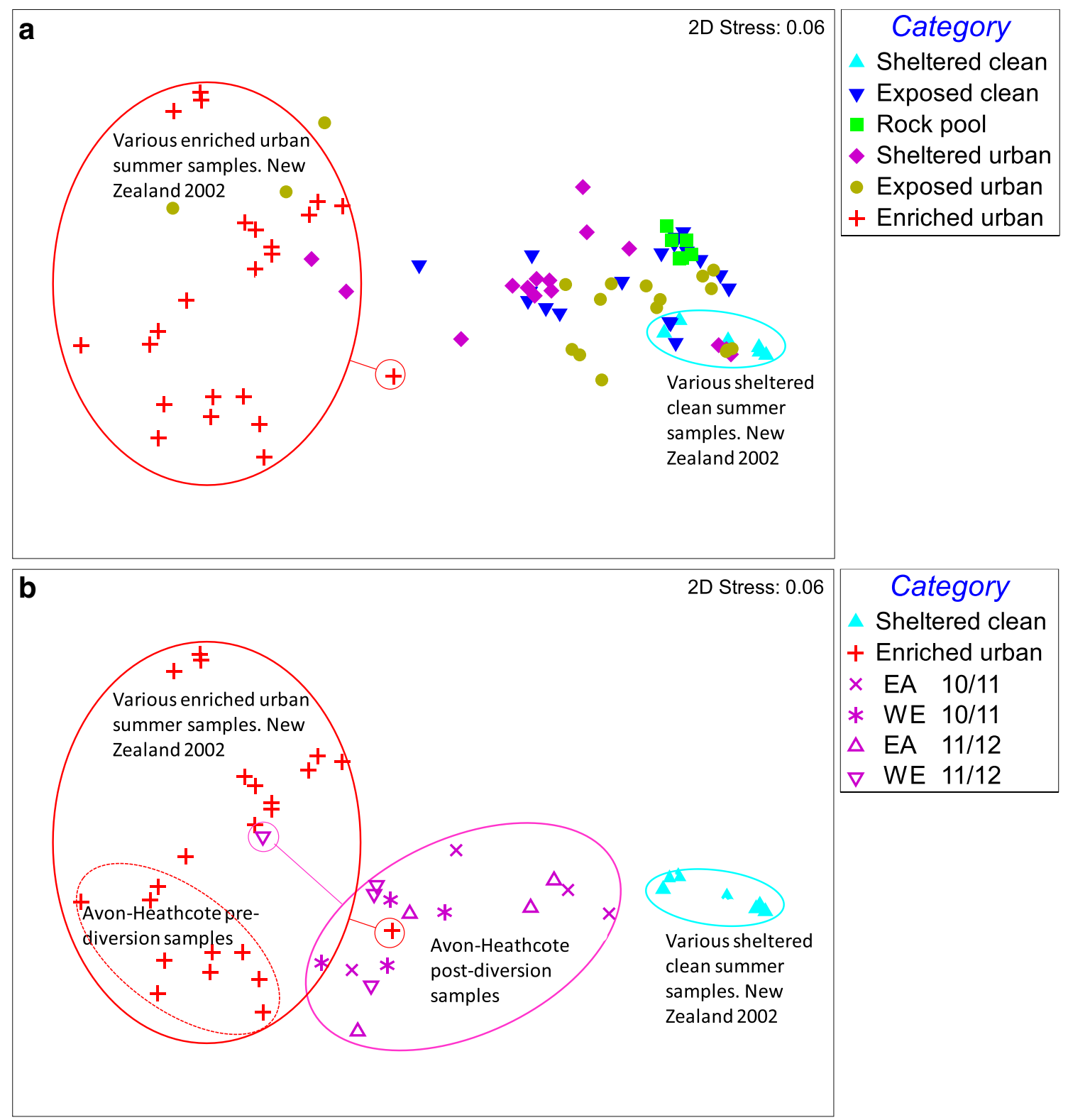

Fig. 8 Multi-dimensional scaling (MDS) of tissue N-indices in Ulva derived from this study and Barr et al. (2013) for 27 sites around New Zealand, divided into environmental categories. Nine Ulva tissue Nindices were used: aspartate, glutamate, asparagine, glutamine, proline, and total remaining free amino acids, chlorophyll $(a+b)$, tissue- $\mathrm{N}$ and tissue- $\delta{ }^{15} \mathrm{~N}$. The nine $\mathrm{N}$-indices were transformed using a square root transformation and were then used to produce a resemblance matrix. The matrix was used to generate a Euclidian Distance MDS plot that

western sites. Moreover, the shift in biochemical N-indices in Ulva could be seen in the context of populations over a much larger national context, over time. The fact that Ulva samples from the AHE in the summers of 2002/2003 and 2009/2010 existed in the same multi-dimensional space, and then changed after the diversion in the following two summers (2010/2011 and 2011/2012), suggest that the broad biochemical processes and resulting N-status in Ulva, for a given population, exist in a dynamic equilibrium with the environment, at least through examined relative similarity/dissimilarity of $\mathrm{N}$-indices in Ulva populations using PRIMER (version 6.1.7) as below. a Ulva tissue $\mathrm{N}$-indices for 6 environmental categories that cross exposure and eutrophication gradients sampled in 2002 (from Barr et al. 2013). b Changes in postdiversion AHE Ulva relative to Ulva from sheltered clean and urban enriched estuaries only, for the 2002 surveys and including samples from AHE in pre- (2009/2010) and post-diversion (2010/2011 and 2011/2012) periods

summer seasonal peak growth. As such, this is often when we are concerned about potential macroalgal blooms, so detecting these biochemical shifts over inter-annual time scales potentially offers a method for early detection of insidious, problem-causing changes in estuaries. One caveat that must be acknowledged though is the roll of water velocity and wave exposure on tissue $\mathrm{N}$-status, due to enhanced rates of $\mathrm{N}$ uptake in Ulva (for discussion of this see Barr et al. 2008). However, given the evidence provided in the comparison here, the observed changes 

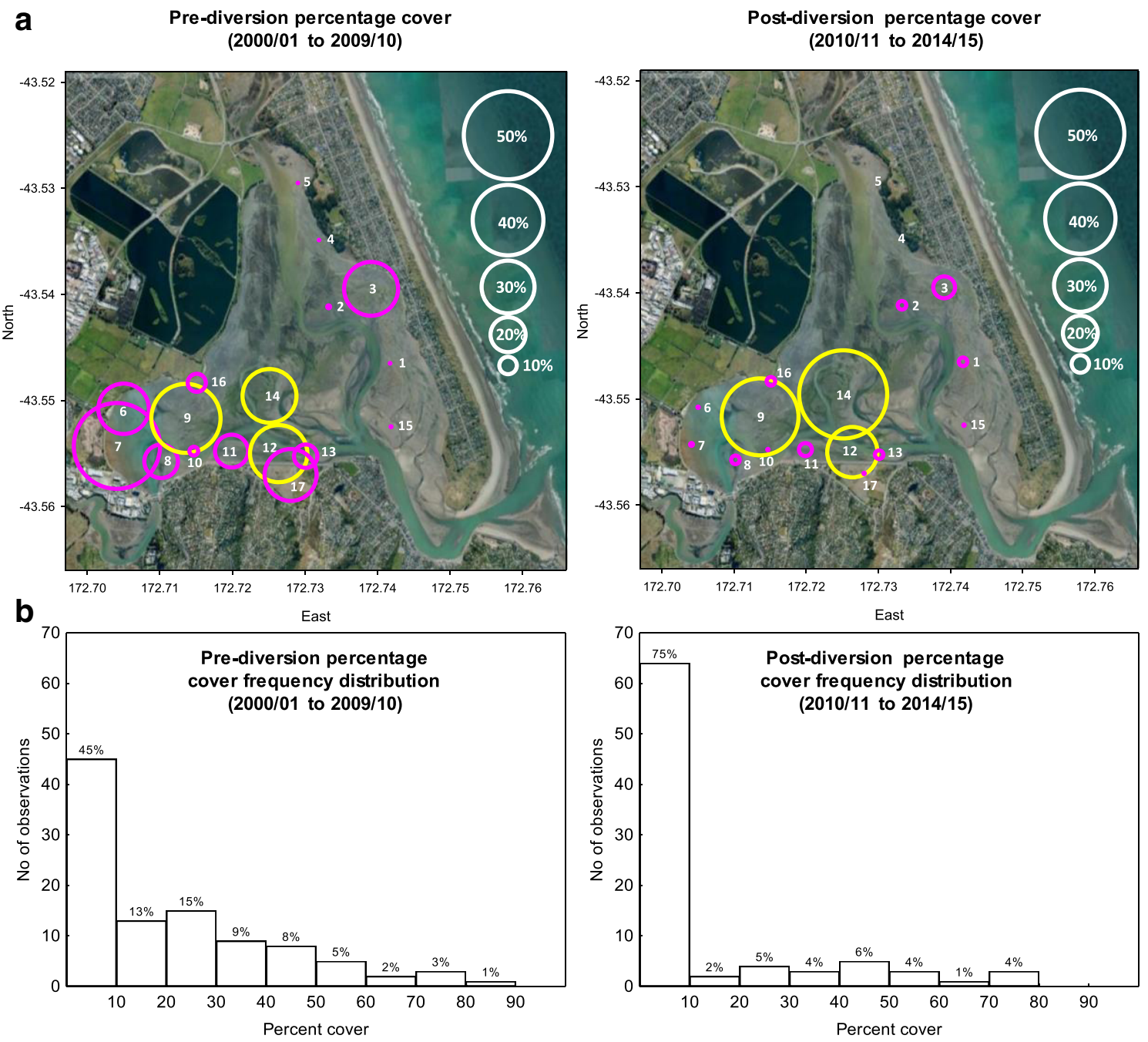

Fig. 9 a Top two panels comparing median percentage cover of Ulva in the AHE in the pre-diversion period (2001 to 2010) and the postdiversion period (2010 to 2015). Yellow circles show the three known 'seed site' areas $(9,12$ and 14) and the pink are 'accumulation' sites (see Methods). The white circles are a scale key. b Top two panels comparing frequency distributions of percentage cover for Ulva in the AHE in the

in N-status over time would appear to be largely a function of changes in $\mathrm{N}$-availibility, as opposed to the changes in water motion over time, that would be required to explain such observed shifts.

As indices of N-availability in the seawater column, tissuechlorophyll and -FAA content in Ulva showed the strongest responses (percentage change, Fig. 6) to the diversion of wastewater-derived $\mathrm{N}$, while the percentage change in tissue-N was less dramatic (Fig. 6). However, the fact that Ulva tissue-N declined from pre-diversion saturating summer levels ( 4\%, Björnsäter and Wheeler 1990) to lower postdiversion levels suggests it is likely the reduction in seawater $\mathrm{N}$-concentration was to some extent impinging on potential summer growth rate in AHE Ulva. It is also worth noting that while $\mathrm{N}$-indices mentioned above (tissue-chlorophyll, -FAA and $-\mathrm{N}$ ) showed clear post-diversion reductions, they did not

pre-diversion summers (2001/2002 to 2009/2010) and post-diversion summers (2010/2011 to 2014/2015). Frequency distributions were fitted and tested for differences between pre- and post-diversion frequency distributions (chi-square), where the expected result under the null hypothesis was that pre- and post-diversion distributions were the same (chisquare $=42.34, \mathrm{df}=9, P<0.001$ )

fall to average minimum values observed in Ulva populations with low water column $\mathrm{N}$ loading from around New Zealand (Barr 2007), indicating Ulva in the AHE still had a moderate $\mathrm{N}$-status and $\mathrm{N}$-availability from the water column.

Tissue-Chlorophyll Chlorophyll content in macroalgae has long been known to increase with external nitrogen concentration and as such is largely considered as a metabolically active pool but because of its small size is not considered to be significant for $\mathrm{N}$-storage (McGlathery et al. 1996). Irrespective of this, chlorophyll content can offer a simple relative measure of change in $\mathrm{N}$-availability assimilated into algal tissue, at least partly because chlorophyll levels are easily determined (Buapeta et al. 2008), but also because in this study, it showed a clear shift with the pre- versus postdiversion change in $\mathrm{N}$ loading in the estuary. 
Tissue-FAA Compared with the $\mathrm{N}$ bound in chlorophyll, $\mathrm{N}$ bound in FAA in macroalgae can make up a considerable percentage of the tissue-N content, with values up to $47 \%$ in red (Wilcox et al. 2006), $55 \%$ in green (McGlathery et al. 1996) and $53 \%$ in brown (Zimmermann and Kremer 1986) macroalgae. However, the range of the FAA pool within individual algal species can also vary with respect to its contribution to tissueN. For example, the percentage contribution of FAA to TTN can range from 8-45\% in Chaetomorpha linum (McGlathery et al. 1996), 4-9 \% in Ulva fenestrate (Naldi and Wheeler 1999) and 7-70 \% in Gracilaria tikvahiae (Bird et al. 1982). While some of these changes may be due to the factors identified above (e.g. maintaining N-metabolism), there are few studies that have quantified the relationship between FAA content (including glutamine and glutamate) in macroalgae and sustained long-term nitrogen supply at ecologically relevant concentrations. The study of Barr and Rees (2003) showed the FAA pool in Ulva species can show rapid (within a single tidal cycle) and large responses to $\mathrm{N}$ contribution from the water column, while other studies have shown that of certain individual FAAs in Gracilaria can respond differently to different $\mathrm{N}$-sources (e.g. $\mathrm{NO}_{3}{ }^{-}$versus $\mathrm{NH}_{4}{ }^{+}$) in seawater (Jones et al. 1996).

Tissue-N As above, total tissue- $\mathrm{N}$ was less responsive to changes in N loading (compared with chlorophyll and FAA as above) - probably because, as others show (Atkinson and Smith 1983; Barr and Rees 2003; Barr 2007), it integrates over longer time scales (days to weeks), and is more likely to reflect seasonal differences in nutrient uptake and growth. Fluctuating seasonal tissue- $\mathrm{N}$ has been found in several temperate macroalgal species, with tissue- $\mathrm{N}$ tending to increase towards saturation in winter months as growth rate becomes limited by light and/or temperature (DeBoer 1981). This means that although tissue-N is likely to reflect changing N-supply (Chapman and Craigie 1977; Rosenberg and Ramus 1982; Wheeler and Weidner 1983; Thomas and Harrison 1985), it is unlikely to be linearly related to it. Regardless, our study revealed a clear summer response of tissue- $\mathrm{N}$ to changes in enrichment following the diversion. Ulva from the two sites maintained saturated levels of $\sim 4 \%$ or more in the year preceding the diversion (Figs. 6 and 7). Then, in the summer following the diversion, there was a marked decline in tissue- $\mathrm{N}$ to $<2 \%$ at the western site and $3 \%$ at the western site by the end of the study. The more intermediate tissue-N values in the following 2012/2013 summer were likely caused by elevated $\mathrm{N}$-supply due to earthquake-related enrichment occurring over 2011. By the 2012-2013 summer, these effects had disappeared, reflecting the improved water quality following the infrastructure repair. However, the positive effects of diversion at the western site were less pronounced than at the eastern site, presumably because the western site was strongly affected by Heathcote River DIN inputs (Fig. 4), which were not remediated by the wastewater diversion.
Generally, Ulva at the western site had slightly higher levels of pre- and posted-diversion tissue- $\mathrm{N}$ (and other N-indices, see Fig. 6) consistent with the higher $\mathrm{N}$ loadings (see Table 1) at the western site (compared with those at the eastern site). Interestingly, some early trial Ulva growth assays were conducted just before and after the diversion showing that growth rate was slightly higher in Ulva from the western site compared with Ulva from the eastern site (unpublished data). This is consistent with the observation that growth rate in Ulva can be correlated (albeit non-linearly) with tissue- $\mathrm{N}$ (N-status) as shown by Björnsäter and Wheeler (1990).

Tissue $-\delta{ }^{15} \mathrm{~N}$ One of the clearest shifts in AHE algal N-indices was seen in Ulva tissue- $\delta{ }^{15} \mathrm{~N}$, with marked deviations from the marine $\mathrm{N}$-isotopic coastal water baseline signature $(\sim 6.6$ $8.8 \%$ ) of Barr et al. (2013) for New Zealand. Nitrogen incorporated in the growing tissues of macroalgae such as Ulva integrate the $\delta^{15} \mathrm{~N}$ signature of biologically available DIN in seawater (McClelland and Valiela 1998; Costanzo et al. 2001; Jones et al. 2001; Fry et al. 2003; Costanzo et al. 2005). Ulva $\delta^{15} \mathrm{~N}$ showed a significant shift in the sources of $\mathrm{N}$ in the estuary over the duration of this study. Prior to the wastewater diversion, $\delta^{15} \mathrm{~N}$ switched from high $(>>8.8 \%$ o) values in summer 2009 to low $(<<6.6 \%$ ) values in winter, then back again to high values in summer 2009/2010. Before the diversion, the effluent was discharged directly into estuary from the CWTP oxidation and retention ponds. It is probable that the incoming raw effluent $\delta^{15} \mathrm{~N}$ signature was low $\sim 0 \%$ (Heaton 1986; Bedard-Haughn et al. 2003; Dudley 2008; Barr et al. 2013) which persisted through the secondary wastewater treatment plant to the discharge in the estuary because of low winter temperatures and reduced biological processing of $\mathrm{N}$ in the ponds. In the summer, increased ammonia volatilisation and denitrification would remove more ${ }^{14} \mathrm{~N}$ from the wastewater than ${ }^{15} \mathrm{~N}$, resulting in an increase in $\delta^{15} \mathrm{~N}$ values of the remaining DIN. Prior to the diversion of wastewater from the estuary, this summer-to-winter shift from high to low $\delta^{15} \mathrm{~N}$ was reflected in Ulva tissue- $\delta^{15} \mathrm{~N}$ signature.

By the end of the study, Ulva tissue- $-\delta^{15} \mathrm{~N}$ values on both eastern and western sides of the estuary had stabilised at values that were near but slightly above the $6.6-8.8 \%$ baseline of Barr et al. (2013), reflecting a much higher relative contribution of marine $\mathrm{N}$ to the estuary. The relative stability of the isotopic signal at the eastern site, compared with that of the western site, was probably a reflection of its greater distance from a river (the Heathcote River), and the stronger influence of the more stable marine end-member $\delta^{15} \mathrm{~N}$ here. Barr et al. (2012) reported that Heathcote River ${ }^{15} \mathrm{NO}_{3}{ }^{-}$values were approximately $10 \%$, which is consistent with the slightly elevated ${ }^{15} \mathrm{~N}$ levels at the western compared to eastern site. In addition, both sites showed elevated ${ }^{15} \mathrm{~N}$ values above the marine baseline, which could also in part be accounted for by estuarine denitrification driven selective removal of ${ }^{14} \mathrm{~N}$ 
(Bedard-Haughn et al. 2003). Irrespective, previous work has shown that Ulva shows minimal discrimination at uptake against isotopically heavier (or lighter) forms of $\mathrm{N}$ (Dudley et al. 2010. See also Cohen and Fong 2005) and has been shown to distinguish between distinct $\delta^{15} \mathrm{~N}$-source pools in natural ecosystems (Cornelisen et al. 2007). Therefore, it is reasonable and logical to assume that Ulva tissue- $\delta \delta^{15} \mathrm{~N}$ in the AHE has reflected the substantial relative changes in the mixed sources of ${ }^{15} \mathrm{~N}$ that have undoubtedly occurred over the duration of this study.

\section{Changes in Ulva Biomass}

Percentage cover of the AHE by Ulva significantly reduced from pre-diversion levels to post-diversion levels (12.1 to $2.8 \%$, respectively, for median values: Fig. 9b). However, we note that percentage cover estimates, while being a commonly used tool for monitoring macroalgal changes in estuaries, may underestimate the actual biomass (e.g. Sutula et al. 2014). This is because percentage cover does not evaluate thickness of Ulva beds (e.g. Alexander et al. 2008), with a potentially large variation in the thickness of surface algae for a given percentage cover, especially when cover is high (Sfriso et al. 1991; Bressington 2003; Alexander et al. 2008; Sutula et al. 2014). Therefore, we consider it likely that the reductions in percentage cover observed in the AHE underestimated the actual reductions in biomass.

The reduction in Ulva standing stocks in the estuary included reductions in percentage cover at sites 6 and 7 (western AHE) from $40 \%$ pre-diversion to $<10 \%$ cover, post-diversion. This was also a part of the estuary that had suffered from significant pre-diversion (beach-cast) accumulations of Ulva. It is possible that in this part of the estuary, a change in tidal immersion period due to seabed uplift in the western AHE caused by the February 2011 earthquake $(0.2$ to $0.3 \mathrm{~m}$, Measures et al. 2011) may have partly contributed to the reduction of percentage algal cover observed here. However, this change was relatively minor relative to the mean tidal range of the AHE $(\sim 2 \mathrm{~m})$. Furthermore, percentage cover at sites 6 and 7 had already decreased to $<10 \%$ levels in the 2010/2011 summer prior to the February 2011 earthquake, 11 months after the diversion. This suggested that the diversion had a dominant effect at these western sites relative to earthquake effects (as also concluded by Bolton-Ritchie 2015). Changes in earthquake-driven bed height at the other CCC monitoring sites where Ulva had historically accumulated were all relatively minor $(0.00$ to $0.05 \mathrm{~m}$, Measures et al. 2011).

There were situations in the AHE where high Ulva cover persisted after the diversion, in areas dominated by cockle shells (sites 9, 12 14) or coarse sand (8). These substrate types provide good attachment for Ulva, and as result these sites also typically supported Ulva germlings (young Ulva thalli) in thin layers all year-round. As such, these sites were classified as 'seed sites'. In addition, in places where 'seed' Ulva persisted through the year, these areas also probably supported overwintering biomass (albeit at low levels) (T. Costello CCC, personal communication, June 2015) because of good substrate available for attachment (as suggested by Hawes and O'Brien 2000). Conversely areas where substrate is less ideal for attachment (e.g. areas with persistent layers of fine sediment), or areas where there is high water velocity associated with tidal currents or strong winds, may not support an extensive overwintering biomass (Hawes and O'Brien 2000). However, it should be noted that bloom-forming Ulva have also been shown to use multiple reproductive strategies for overwintering (Rinehart et al. 2014); therefore even if reductions in seed Ulva did occur, this may not necessarily translate to changes in peak season standing stock. Hence, the observed reduction in Ulva percentage cover (and its standing stock) is most likely a direct result of the reduction in $\mathrm{N}$ loading in the AHE.

Another cause of post-diversion persistent Ulva cover occurred at sites known to trap drifting algae at 'accumulation' sites (e.g. sites 1 and 3). It is likely that once Ulva germlings ('seeds') reach a threshold size during peak growth periods (summer), they detach from the substrate and drift away, as observed and modelled for the AHE by Hawes and Smith (1995). Site 1 is a seagrass bed, which traps drifting Ulva, and site 3 is a site where drifted Ulva accumulated to the extent that it required removal by truck from the shoreline in most years prior to the diversion. Both sites have, however, seen greatly lessened accumulation, post-diversion (Fig. 9). Other sites that have seen no change (sites 4 and 5) were those which never had high percentage cover either pre- or postdiversion.

\section{Changes in $\mathbf{N}$ Loading}

Ulva biochemical monitoring began approximately 1 year prior to the March 2010 wastewater diversion, which was expected to reduce $\mathrm{N}$ loading to the AHE by an estimated $90 \%$ (Bolton-Ritchie 2015). This was followed by a reintroduction of $\mathrm{N}$ loading ( $\sim 21 \%$ of the pre-diversion wastewater $\mathrm{N}$ load) caused by damage to wastewater infrastructure from the earthquakes and sewage flows from the rivers, from February to November 2011. Regardless of the earthquake effects, since the diversion, there have been large reductions of $\mathrm{NH}_{4}-\mathrm{N}$ and DRP. It was notable, however, that the mean response of DIN at the six water quality sites (Table 1) was less than the $90 \%$ figure, above. This was explicable in that the latter figure is a budget estimate made by comparing CWTP inputs with river and smaller drain inputs (Bolton-Ritchie 2015) whereas the estimate from the six sites included sampling at two sites strongly influenced by the Avon and Heathcote Rivers. Because $\mathrm{NO}_{3}-\mathrm{N}$ loading to the estuary is largely riverine, 
and the rivers have not been remediated, our estimate of DIN reduction showed a less pronounced response to the diversion than expected from the estuary-wide budget.

\section{Conclusion}

The shift in both Ulva biochemical indicators and Ulva abundance since the diversion of wastewater from the AHE clearly reflects a reduction in $\mathrm{N}$ loading over time, and at two separate locations in one estuary. This shift in indicted trophic condition (as a function of $\mathrm{N}$ loading) was also demonstrated within a much broader (regional) context when compared with samples collected from around New Zealand (Barr et al. 2013). By 2011 (one year after the diversion), the trophic condition of AHE Ulva (indicated by multivariate analysis of algal bioindicators) had shifted away from an 'enriched urban' status, part-way towards that of 'sheltered clean' estuary status, using the classification of Barr et al. (2013). The fact that the results for 2010-11 and 2011-12 'shift' were intermingled in multivariate space (Fig. 9) probably indicated the temporary impact of the February and June 2011 earthquakes in this progression away from eutrophication. It is also likely that enrichment from the Avon and Heathcote Rivers has an ongoing effect on the AHE's water quality which continues to affect the trajectory of change reflected in Ulva biochemistry, albeit with a much-reduced level of Ulva biomass, compared to pre-wastewater diversion conditions. Further monitoring of the biochemistry and biomass of the algae will help verify this effect and the extent to which the estuary eventually reaches a completely non-impacted state. However, the data indicate that this estuary has shown significant and rapid recovery away from eutrophication caused by heavy urban wastewater nitrogen (and nutrient) loading, supporting our hypothesis that recovery would be rapid after wastewater diversion.

The rapid responses of the algal biochemical and percentage cover indicators to reduced water column $\mathrm{N}$ loading indicated trophic resilience to eutrophication in the AHE, driven primarily from the water column. This was consistent with the findings of Zeldis et al. (2019) who found rapid recovery of ecological health in the AHE across multiple benthic indicators, including a large reduction in eutrophic microalgal biomasses. They ascribed this response to the physiography of the AHE: well-flushed tidal lagoon, with sediments that were sandy rather than muddy, well irrigated, and sustained low organic matter contents. This physiography precluded a strong sediment role in eutrophication, in terms of a long-lived legacy of nutrient-release driven by accumulated sediment organic matter.

By exploiting the rapid shifts in N-enrichment caused by the wastewater diversion and the impact of the Christchurch earthquakes, our study has demonstrated several advantages presented by biochemical macroalgal bioindicators in eutrophication assessment with respect to water quality monitoring. Macroalgae are generally present at one site over long periods (from tidal cycles, to days and weeks) and therefore integrate information about average biologically available $\mathrm{N}$. On the other hand, nutrient levels from water quality monitoring are subject to tidal-state aliasing (e.g. Fig. 2) as well as seasonal aliasing caused by nutrient incorporation into the algae itself (Thybo-Christesen et al. 1993; Flindt et al. 1999). Unlike water quality measures as determinants of eutrophication, macroalgal bioindicators can identify N-sources that drive eutrophication (e.g. ${ }^{14} \mathrm{~N} /{ }^{15} \mathrm{~N}$ ratio differences between wastewater and other estuarine end-members, e.g. rivers/ocean) as well as describe the location and trajectory of a macroalgal community on the gradient from nitrogen saturated to 'clean estuary' conditions. Finally, they add direct physiological understanding of drivers of macroalgal production when accompanied by macroalgal biomass/cover surveys.

Acknowledgements This work was supported primarily by New Zealand Ministry for Business, Innovation and Employment contract number UOCX0902 and also partially by NIWA SSIF contract number FWWQ1712. Thanks to Mike Bourke for CWTP wastewater flow data and Terry Costello for algal percentage cover estimates (both Christchurch City Council) and Lesley Bolton-Ritchie (Environment Canterbury) for estuary water quality data. Thanks to the University of Auckland and my supervisors at that time, Alwyn Rees and Richard Taylor for supporting my $\mathrm{PhD}$ research from which some of the early data used in this manuscript is derived. From the University of Canterbury thank you to Paul South and Michael Greer, and to staff from NIWA, Laura Drummund and Catie Gongol, for field assistance and sample analyses.

Open Access This article is distributed under the terms of the Creative Commons Attribution 4.0 International License (http:// creativecommons.org/licenses/by/4.0/), which permits unrestricted use, distribution, and reproduction in any medium, provided you give appropriate credit to the original author(s) and the source, provide a link to the Creative Commons license, and indicate if changes were made.

\section{References}

Alexander, D.J., D.E. Hart, and I.D. Marsden. 2008. Evaluation and development of techniques to map macroalgae in the Avon-Heathcote Estuary Ihutai. Estuarine Research Report 35. Avon-Heathcote Estuary Trust, Christchurch City Council and Environment Canterbury. $84 \mathrm{pp}$.

ANZECC. 2000. Australian and New Zealand guidelines for fresh and marine water quality. Australian and New Zealand Environment and Conservation Council, Agriculture and Resource Management Council of Australia and New Zealand.

APHA. 1998. Standard Methods for the examination of water and waste water, 874. American Public Health Association.

Atkinson, M.S., and S.V. Smith. 1983. C:N:P ratios of benthic marine plants. Limnology and Oceanography 28: 568-574.

Barr, N.G. 2007. Aspects of nitrogen metabolism in the green alga Ulva; Developing an indicator of seawater nitrogen loading. $\mathrm{PhD}$ Thesis, University of Auckland Research Space. URL: http://hdl.handle.net/ $2292 / 2522$ 
Barr, N.G., and T.A.V. Rees. 2003. Nitrogen status and metabolism in the green seaweed Enteromorpha intestinalis: an examination of three natural populations. Marine Ecology Progress Series 249: 133-144.

Barr, N.G., A. Kloeppel, T.A.V. Rees, C. Scherer, R.B. Taylor, and A. Wenzel. 2008. Wave surge increases rates of growth and nutrient uptake in the green seaweed Ulva pertusa maintained at low bulk flow velocities. Aquatic Biology 3: 179-186.

Barr, N.G., J. Zeldis, C. Gongol, L. Drummond, and K. Scheuer. 2012. Effects of the Canterbury earthquakes on Avon-Heathcote Estuary/ Ihutai macroalgae. NIWA Client Report No: CHC2012-072 Prepared for Environment Canterbury and Christchurch City Council.

Barr, N.G., B.D. Dudley, K.R. Rogers, and C.D. Cornelisen. 2013. Broad-scale patterns of tissue- $\delta^{15} \mathrm{~N}$ and tissue-N indices in Ulva; Developing a national baseline indicator of nitrogen-loading for coastal New Zealand. Marine Pollution Bulletin Baseline, Marine Pollution Bulletin 67 (1-2): 203-216.

Bedard-Haughn, A., J.W. van Groenigen, and C. van Kessel. 2003. Tracing ${ }^{15} \mathrm{~N}$ through landscapes: potential uses and precautions. Journal of Hydrology 272: 175-190.

Bird, K.T., C. Habig, and T. DeBusk. 1982. Nitrogen allocation and storage patterns in Gracilaria tikvahiae (Rhodophyta). Journal of Phycology 18: 344-348.

Björnsäter, B.R., and P.A. Wheeler. 1990. Effect of nitrogen and phosphorus supply on growth and tissue composition of Ulva fenestrata and Enteromorpha intestinalis (Ulvales, Chlorophyta). Journal of Phycology 26: 603-611.

Bokn, T.L., F.E. Moy, H. Christie, S. Engelbert, R. Karez, K. Kersting, P. Kraufvelin, C. Lindblad, N. Marba, M.F. Pedersen, and K. Sorensen. 2002. Are rocky shore ecosystems affected by nutrientenriched seawater? Some preliminary results from a mesocosm experiment. Hydrobiologia 484: 167-175.

Bolton-Ritchie, L. 2015. The sediments and biota within the Estuary of the Heathcote and Avon Rivers/Ihutai 2007-2013. Technical Report Investigations and Monitoring Group, 978-0-478-15185-5: 102.

Bolton-Ritchie, L., and M. Main. 2005. Nutrient water quality Avon Heathcote Estuary/Ihutai. Environment Canterbury Technical Report: 82 pp.

Bressington, M. 2003. The effects of macroalgae mats on the marine benthic fauna in the Avon Heathcote Estuary, MSc thesis (Environmental Science), University of Canterbury, New Zealand, $138 \mathrm{pp}$.

Buapeta, P., R. Hiranpan, R.J. Ritchie, and A. Prathep. 2008. Effect of nutrient inputs on growth, chlorophyll, and tissue nutrient concentration of Ulva reticulata from a tropical habitat. ScienceAsia 34: 245-252.

Chapman, A.R.O., and J.S. Craigie. 1977. Seasonal growth in Laminaria longicruris: relations with dissolved inorganic nutrients and internal reserves of nitrogen. Marine Biology 40: 197-205.

Cloern, J.E., E.A. Canuel, and D. Harris. 2002. Stable carbon and nitrogen isotope composition of aquatic and terrestrial plants of the San Francisco Bay estuarine system. Limnology and Oceanography 47: $713-729$.

Cohen, R.A., and P. Fong. 2005. Experimental evidence supports the use of $\delta^{15} \mathrm{~N}$ content of the opportunistic green macroalga Enteromorpha intestinalis (Chlorophyta) to determine nitrogen sources to estuaries. Journal of Phycology 41: 287-293.

Cohen, R.A., and P. Fong. 2006. Using opportunistic green macroalgae as indicators of nitrogen supply and sources to estuaries. Ecological Applications 16 (4): 1405-1420.

Cornelisen, C.D., S.R. Wing, K.L. Clark, M.H. Bowman, R.D. Frew, and C.L. Hurd. 2007. Patterns in the $\delta^{13} \mathrm{C}$ and $\delta^{15} \mathrm{~N}$ signature of Ulva pertusa: interaction between physical gradients and nutrient source pools. Limnology and Oceanography 52: 820-832.
Costanzo, S.D., M.J. O’Donohue, W.C. Dennison, N.R. Loneragan, and M.T. Thomas. 2001. A new approach for detecting and mapping sewage impacts. Marine Pollution Bulletin 42 (2): 149-156.

Costanzo, S.D., J. Udy, B. Longstaff, and A. Jones. 2005. Using nitrogen stable isotope ratios $\left(\delta^{15} \mathrm{~N}\right)$ of macroalgae to determine the effectiveness of sewage upgrades: changes in the extent of sewage plumes over four years in Moreton Bay, Australia. Marine Pollution Bulletin 51 (1-4): 212-217.

DeBoer, J.A. 1981. Nutrients. In The biology of seaweeds, ed. C.S. Lobban and M.J. Wynne, 356-392. Oxford: Blackwell Scientific Publications.

Dudley, B.D. 2008. Quantitative ecological impact assessments using natural abundance carbon and nitrogen stable isotope signatures. $\mathrm{PhD}$ thesis, Victoria University of Wellington, Wellington. URL: http://hdl.handle.net/10063/455.

Dudley, B.D., N.G. Barr, and J.S. Shima. 2010. The influence of light intensity and nutrient source on $\delta^{13} \mathrm{C}$ and $\delta^{15} \mathrm{~N}$ signatures in Ulva pertusa. Aquatic Biology 9: 85-93.

Duke, C.S., W. Litaker, and J. Ramus. 1989. Effects of temperature, nitrogen supply, and tissue nitrogen on ammonium uptake rates of the chlorophyte seaweeds Ulva curvata and Codium decorticatum. Journal of Phycology 25: 113-120.

Duncan, M.J., and P.J. Harrison. 1982. Comparison of solvents for extracting chlorophylls from marine macrophytes. Botanica Marina 25: 445-447.

EU Water Framework Directive. 2000/60/EC. Official Journal of European Commission L327: 1-72.

Flindt, M.R., J.A. Pardal, A.I. Lillebo, I. Martins, and J.C. Marques. 1999. Nutrient cycling and plant dynamics in estuaries: a brief review. Acta Oecologica-International Journal of Ecology 20: 237-248.

Flynn, K.J., D.M.J. Dickson, and O.A. Al Amoudi. 1989. The ratio of glutamine : glutamate in microalgae: a biomarker for nitrogen status suitable for use at natural cell densities. Journal of Plankton Research 11, 165-170.

Fong, P., and J.B. Zedler. 1993. Temperature and light effects on the seasonal succession of algal communities in shallow coastal ecosystems. Journal of Experimental Marine Biology and Ecology 171: 259-272.

Fong, P., K.E. Boyer, and J.B. Zedler. 1998. Developing an indicator of nutrient enrichment in coastal estuaries and lagoons using tissue nitrogen content of the opportunistic alga, Enteromorpha intestinalis (L. Link). Journal of Experimental Marine Biology and Ecology 231: 63-79.

Fowler, D., M. Coyle, U. Skiba, M.A. Sutton, J.N. Cape, S. Reis, L.J. Sheppard, A. Jenkins, B. Grizzetti, and J.N. Galloway. 2013. The global nitrogen cycle in the twenty-first century. Philosophical Transactions of the Royal Society B 368 (1621): 20130164.

Fry, B., A. Gace, and J.M. McClelland. 2003. Chemical indicators of anthropogenic nitrogen loading in four Pacific estuaries. Pacific Science 57: 77-101.

GESAMP. 2001. Protecting the oceans from land-based activities. Landbased sources and activities affecting the quality and uses of the marine, coastal and associated freshwater environment. United Nations Environment Program, Nairobi.

Hanisak, M.D. 1983. The nitrogen relationships of marine macroalgae. In Nitrogen in the marine environment, ed. E.J. Carpenter and D.G. Capone, 699-730. New York: Academic Press.

Hawes, I., and R. O'Brien. 2000. Contribution to the assessment of the effects of the Bromley oxidation ponds effluent on the AvonHeathcote Estuary: modelling the growth of sea lettuce in the estuary. NIWA Client Report: CHC00/19.

Hawes, I., and R. Smith. 1995. Effect of current velocity on the detachment of thalli of Ulva lactuca (Chlorophyta) in a New Zealand estuary. Journal of Phycology 31: 875-880. https://doi.org/10. 1111/j.0022-3646.1995.00875. 
Heaton, T.H.E. 1986. Isotopic studies of nitrogen pollution in the hydrosphere and atmosphere: a review. Chemical Geology: Isotope Geoscience 5: 87-102.

Holden, M. 1965. Chlorophylls. In Chemistry and biochemistry of plant pigments, ed. T.W. Goodwin, 461-488. New York: Academic Press.

Jones, A.B., W.C. Dennison, and G.R. Stewart. 1996. Macroalgal responses to nitrogen source and availability: amino acid metabolic profiling as a bioindicator using Gracilaria edulis (Rhodophyta). Journal of Phycology 32: 757-766.

Jones, A.B., M.J. O'Donohue, J. Udy, and W.C. Dennison. 2001. Assessing ecological impacts of shrimp and sewage effluent: biological indicators with standard water quality analyses. Estuarine, Coastal and Shelf Science 52: 91-109.

Jones, B.L., L.C. Cullen-Unsworth, and R.K.F. Unsworth. 2018. Tracking nitrogen source using $\delta^{15} \mathrm{~N}$ reveals human and agricultural drivers of seagrass degradation across the British Isles. Frontiers in Plant Science 9: 133. https://doi.org/10.3389/fpls.2018.00133.

Knox, G., and A. Kilner. 1973. The Ecology of the Avon-Heathcote Estuary. Christchurch: University of Canterbury.

Lemesle, S., A. Erraud, I. Mussio, A.M. Rusig, and P. Claquin. 2016. Dynamics of $\delta^{15} \mathrm{~N}$ isotopic signatures of different intertidal macroalgal species: assessment of bioindicators of $\mathrm{N}$ sources in coastal areas. Marine Pollution Bulletin 97: 241-254.

McClelland, J.W., and I. Valiela. 1998. Linking nitrogen in estuarine producers to land-derived sources. Limnology and Oceanography 43: $577-585$.

McClelland, J.W., I. Valiela, and R.H. Michener. 1997. Nitrogen-stable isotope signatures in estuarine food webs: a record of increasing urbanization in coastal watersheds. Limnology and Oceanography 42: 930-937.

McGlathery, K.J., M.F. Pedersen, and J. Borum. 1996. Changes in intracellular nitrogen pools and feedback controls on nitrogen uptake in Chaetomorpha linum (Chlorophyta). Journal of Phycology 32: 393401.

Measures, R., M. Hicks, U. Shankar, J. Bind, J. Arnold, and J. Zeldis. 2011. Mapping earthquake induced topographic change and liquefaction in the Avon-Heathcote Estuary. NIWA Client Report CHC2011-066: 28 pp.

Morris, J.T. 1991. Effects of nitrogen loading on wetland ecosystems with particular reference to atmospheric deposition. Annual Review of Ecology and Systematics 22: 257-279.

Naldi, M., and P. Wheeler. 1999. Changes in nitrogen pools in Ulva fenestrata (Chlorophyta) and Gracilaria pacifica (Rhodophyta) under nitrate and ammonium enrichment. Journal of Phycology 35: 70-77.

Nixon, S.W. 1995. Coastal marine eutrophication: a definition, social causes, and future concerns. Ophelia 41: 199-219.

NRC. 2000. Clean Coastal Waters: understanding and reducing the effects of nutrient pollution, 405. Washington DC: National Academy Press.

Peckol, P., B. DeMeo-Anderson, J. Rivers, I. Valiela, M. Maldonado, and J. Yates. 1994. Growth, nutrient uptake capacities and tissue constituents of the macroalgae Cladophora vagabunda and Gracilaria tikvahiae related to site-specific nitrogen loading rates. Marine Biology 121: 175-185.

Rinehart, S., M. Guidone, A. Ziegler, T. Schollmeier, and C.S. Thornber. 2014. Overwintering strategies of bloom-forming Ulva species in Narragansett Bay, Rhode Island, USA. Botanica Marina 57 (4). https://doi.org/10.1515/bot-2013-0122.

Rogers, K.M. 1999. Effects of sewage contamination on macroalgae and shellfish at Moa Point, New Zealand using stable carbon and nitrogen isotopes. New Zealand Journal of Marine and Freshwater Research 33: 181-188.

Rogers, K.M. 2003. Stable carbon and nitrogen isotope signatures indicate recovery of marine biota from sewage pollution at Moa Point, New Zealand. Marine Pollution Bulletin 46 (7): 821-827.

Rosenberg, G., and J. Ramus. 1982. Ecological growth strategies in the seaweeds Gracilaria foliifera (Rhodophyceae) and Ulva sp.
(Chlorophyceae): soluble nitrogen and reserve carbohydrates. Marine Biology 66: 251-259.

Savage, C., R. Elmgren, and U. Larsson. 2002. Effects of sewage-derived nutrients on an estuarine macrobenthic community. Marine Ecology Progress Series 243: 67-82.

Sfriso, A., B. Pavoni, A. Marcomini, and A.A. Orio. 1991. Macroalgae, nutrient cycles and pollutants in the Lagoon of Venice. Estuaries 15: $517-528$.

Sharp, J.H. 1983. The distributions of inorganic nitrogen and dissolved and particulate organic nitrogen in the sea. In Nitrogen in the marine environment, ed. E.J. Carpenter and D.G. Capone, 1-35. New York: Academic Press.

Sigman, D.M., M.A. Altabet, D.C. McCorkle, R. Francois, and G. Fischer. 2000. The $\delta{ }^{15} \mathrm{~N}$ of nitrate in the Southern Ocean: nitrogen cycling and circulation in the ocean interior. Journal of Geophysical Research, Oceans 105: 19599-19614.

Smith, V., G. Tilman, and J. Nekola. 1999. Eutrophication: impacts of excess nutrient inputs on freshwater, marine, and terrestrial ecosystems. Environmental Pollution 100 (1-3): 179-196.

STATISTICA. 2013. STATISTICA (data analysis software system). StatSoft, Inc. www.statsoft.com

Steffensen, D. 1974. An ecological study of Ulva lactuca L. and other benthic algae on the Avon-Heathcote Estuary, Christchurch. PhD thesis (Botany), University of Canterbury, Christchurch, $206 \mathrm{pp}$.

Sutula, M., L. Green, G. Cicchetti, N. Detenbeck, and P. Fong. 2014. Thresholds of adverse effects of macroalgal abundance and sediment organic matter on benthic habitat quality in estuarine intertidal flats. Estuaries and Coasts 37 (6): 1532-1548. https://doi.org/10. 1007/s12237-014-9796-3.

Thomas, T.E., and P.J. Harrison. 1985. Effects of nitrogen supply on nitrogen uptake, accumulation and assimilation in Porphyra perforata (Rhodophyta). Marine Biology 85: 269-278.

Thornber, C.S., M. Guidone, C. Deacutis, I. Green, C.N. Ramsay, and M. Palmisciano. 2017. Spatial and temporal variability in macroalgal blooms in a eutrophied coastal estuary. Harmful Algae 68: 82-96.

Thybo-Christesen, M., M.B. Rasmussen, and T.H. Blackburn. 1993. Nutrient fluxes and growth of Cladophora sericea in a shallow Danish bay. Marine Ecology Progress Series 100: 273-281.

Valiela, I., J. McClelland, J. Hauxwell, P.J. Behr, D. Hersh, and K. Foreman. 1997. Macroalgal blooms in shallow estuaries: controls and ecophysiological and ecosystem consequences. Limnology and Oceanography 42: 1105-1118.

Wada, E., T. Kadonaga, and S. Matsuo. 1975. ${ }^{15} \mathrm{~N}$ abundance in nitrogen of naturally occurring substances and global assessment of denitrification from isotopic viewpoint. Geochemical Journal 9: 139-148.

Wheeler, W.N., and M. Weidner. 1983. Effects of external inorganic nitrogen concentration on metabolism, growth and activities of key carbon and nitrogen assimilatory enzymes of Laminaria saccharina (Phaeophyceae) in culture. Journal of Phycology 19: 92-96.

Wilcox, S.J., N.G. Barr, J. Broom, R.H. Furneaux, and W.A. Nelson. 2006. Using gigartinine to track the distribution of an alien species of Gracilaria in New Zealand. Journal of Applied Phycology. Online publication 19 (4): 313-323. https://doi.org/10.1007/ s10811-006-9138-3.

Williams, M. 1960. Report on a biological investigation of the estuary of the Avon Heathcote Rivers, Christchurch, New Zealand. New Zealand: Christchurch Drainage Board Report, pp 18.

Zeldis, J., C. Depree, C. Gongol, A. Marriner, P. South, and D. Schiel. 2019. Trophic indicators of ecological resilience in a tidal lagoon estuary following wastewater diversion and earthquake-driven disturbance. Estuaries and Coasts (resubmitted $10^{\text {th }}$ July 2019). https:// doi.org/10.1007/s12237-019-00637-8.

Zimmermann, R.C., and J.N. Kremer. 1986. In situ growth and chemical composition of the giant kelp, Macrocystis pyrifera: response to temporal changes in ambient nutrient availability. Marine Ecology Progress Series 27: 277-285. 